\title{
Molecular phylogeny of the tribe Philodryadini Cope, 1886 (Dipsadidae: Xenodontinae): Rediscovering the diversity of the South American Racers
}

\author{
Juan Camilo Arredondo ${ }^{1,6}$; Felipe G. Grazziotin ${ }^{2}$; Gustavo J. Scrocchi ${ }^{3}$; Miguel Trefaut Rodrigues ${ }^{4}$; \\ Sandro Luís Bonatto ${ }^{5}$ \& Hussam Zaher ${ }^{6,7}$
}

1 Universidad CES, Facultad de Ciencias y Biotecnología, Colecciones Biológicas Universidad CES (CBUCES). Medellín, Antioquia, Colombia. ORCID: http://orcid.org/0000-0003-1925-4556. E-mail: jcas36@gmail.com

2 Instituto Butantan, Laboratório Especial de Coleções Zoológicas (LECZ). São Paulo, SP, Brasil. ORCID: http://orcid.org/0000-0001-9896-9722. E-mail: fgrazziotin@gmail.com

${ }^{3}$ Fundación Miguel Lillo, Unidad Ejecutora Lillo (CONICET-UEL). San Miguel de Tucumán, Tucumán, Argentina. ORCID: http://orcid.org/0000-0002-8924-8808. E-mail: gustavo.scrocchi@gmail.com

${ }^{4}$ Universidade de São Paulo (USP), Instituto de Biociências (IB-USP), Departamento de Zoologia. São Paulo, SP, Brasil. ORCID: http://orcid.org/0000-0003-3958-9919. E-mail: mturodri@gmail.com

${ }^{5}$ Pontifícia Universidade Católica do Rio Grande do Sul (PUC-RS), Escola de Ciências da Saúde e da Vida, Laboratório de Biologia Genômica e Molecular. ORCID: http://orcid.org/0000-0002-0064-467X.E-mail: slbonatto@pucrs.br

${ }^{6}$ Universidade de São Paulo (USP), Museu de Zoologia (MZUSP). São Paulo, SP, Brasil.

7 ORCID: http://orcid.org/0000-0002-6994-489X. E-mail: hussam.zaher@gmail.com (corresponding author)

\begin{abstract}
South American racers of the tribe Philodryadini are a widespread and diverse group of Neotropical snakes with a complex taxonomic and systematic history. Recent studies failed to present a robust phylogenetic hypothesis for the tribe, mainly due to incomplete taxon sampling. Here we provide the most extensive molecular phylogenetic analysis of Philodryadini available so far, including 20 species (83\% of the known diversity) from which six were not sampled previously. Our results reveal that Philodryadini is not monophyletic, but instead includes a central Andean clade formed by Philodryas simonsii, $P$. tachymenoides, and P. amaru, and a southern and cis-Andean clade including all remaining philodryadines. This discovery requires resurrection of two genera as well as erection of a new tribe of Xenodontinae for the central Andean clade. Within the southern and cis-Andean radiation, our analyses resolve a basal dichotomy separating two main lineages: Clade A, containing the Common Green Racers P. laticeps and P. viridissima and the South American Vine snakes P. georgeboulengeri and $P$. argentea; and Clade B, including the remaining species of Philodryas sensu stricto. We resurrect the genera Chlorosoma and Xenoxybelis to better represent the monophyly of lineages within the southern and cis-Andean clade.
\end{abstract}

Key-Words. Philodryas; Chlorosoma; Xenoxybelis; Andean Endemism; New Tribe; Hemipenial morphology.

\section{INTRODUCTION}

The South American racers of the tribe Philodryadini Cope 1886 are a diverse and widespread group of snakes with a wide variety of morphologies and ecological roles, ranging from large, semiarboreal, and generalist species to small, secretive, and diet specialist species (Greene \& Jaksic, 1992; Hartmann \& Marques, 2005; Marques et al., 2006). Most of this diversity occurs along the cis-Andean portion of South America (Table 1). Twenty species are distributed from Colombia to Argentina, while only four species inhabit the trans-Andean parts of Ecuador,
Peru, and Chile (Cacciali et al., 2016; Grazziotin et al., 2012; Zaher et al., 2014). Because of their diversity, broad distribution, and variety in ecomorphological traits, the species have a long history of taxonomic instability and uncertainty (Thomas, 1976; Zaher et al., 2008; Wallach et al., 2014).

The unpublished PhD thesis of Robert A. Thomas (1976) was the first large taxonomic review of the genus Philodryas, and several of his conclusions are currently accepted and followed by most researchers. Subsequent taxonomic studies that changed significantly the composition and diversity of the genus were made by Thomas and colleagues (Thomas, 1977; Thomas \& Dixon, 
Table 1. Species diversity and geographical distribution of the members of the tribe Philodryadini (sensu lato). $\mathrm{CE}=\mathrm{Central}, \mathrm{E}=\mathrm{East}, \mathrm{NO}=\mathrm{North}, \mathrm{NE}=\mathrm{Northeastern}$, $\mathrm{NW}=$ Northwestern, $\mathrm{SO}=$ South, $\mathrm{SE}=$ Southeastern, $\mathrm{SW}=$ Southwestern, $\mathrm{W}=$ West, $\mathrm{Ar}=$ Argentina, $\mathrm{C} 0=$ Colombia, $\mathrm{Ch}=\mathrm{Chile}, \mathrm{B} 0=\mathrm{Bolivia}, \mathrm{Br}=\mathrm{Brazil}, \mathrm{EC}=$ Ecuador, $\mathrm{Gu}=$ Guianas, $\mathrm{Pa}=$ Paraguay, $\mathrm{Pe}=$ Peru, $\mathrm{Su}=$ Suriname, $\mathrm{Ve}=$ Venezuela, and $\mathrm{Ur}=$ Uruguay.

\begin{tabular}{|c|c|c|}
\hline Species & Geographical Distribution & Andes related Distribution \\
\hline Ditaxodon taeniatus (Peters, 1868) & SEBr & cis-Andean \\
\hline Philodryas aestiva (Duméril, Bibron \& Duméril, 1854) & NW Ar, Bo, SW-SE-SO Br, Pa, and Ur & cis-Andean \\
\hline Philodryas agassizii (Jan, 1863) & $\mathrm{Ar}, \mathrm{SW}-\mathrm{SO} \mathrm{Br}, \mathrm{Pa}$, and $\mathrm{Ur}$ & cis-Andean \\
\hline Philodryas amaru Zaher et al., 2014 & CE-SOEC & trans-Andean \\
\hline Philodryas argentea (Daudin, 1803) & SO Co, Bo, CE-NO-NE-NW Br, E EC, Gu, E Pe, and SO Ve & cis-Andean \\
\hline Philodryas arnaldoi (Amaral, 1932) & SW Br & cis-Andean \\
\hline Philodryas boliviana Boulenger, 1896 & CEBo & cis-Andean \\
\hline Philodryas baroni Berg, 1895 & NO Ar, W Bo, SW Br, and Pa & cis-Andean \\
\hline Philodryas chamissonis (Wiegmann, 1835) & CE-W Ch & trans-Andean \\
\hline Philodryas cordata Donnelly \& Myers, 1991 & SOVe & cis-Andean \\
\hline Philodryas erlandi Lönnberg, 1902 & $\mathrm{NO} A r, \mathrm{~B} 0$, and $\mathrm{Pa}$ & cis-Andean \\
\hline Philodryas georgeboulengeri (Grazziotin et al., 2012) & Bo, CE-NO-NW Br, and E Pe & cis-Andean \\
\hline Philodryas laticeps Werner, 1900 & CE Bo and SE Br & cis-Andean \\
\hline Philodryas livida (Amaral, 1923) & $\mathrm{SW} \mathrm{Br}$ and $\mathrm{NO} \mathrm{Pa}$ & cis-Andean \\
\hline Philodryas mattogrossensis Koslowsky, 1898 & $\mathrm{SW} \mathrm{Br}$ & cis-Andean \\
\hline Philodryas nattereri Steindachner, 1870 & SW-CE-NE Br and NO Pa & cis-Andean \\
\hline Philodryas olfersii (Lichtenstein, 1823) & CE-NO Ar, SO Co, Bo, Br, E Ec, Gu, Pa, E Pe, Su, SO Ve, and Ur & cis-Andean \\
\hline Philodryas patagoniensis (Girard, 1858) & SO-CE-NO Ar, Bo, SO-SE-CE-NE Br, Pa, and Ur & cis-Andean \\
\hline Philodryas psammophidea Günther, 1872 & NW Ar and SW Br & cis-Andean \\
\hline Philodryas simonsii Boulenger, 1900 & CE-SO Ec and Pe & trans-Andean \\
\hline Philodryas tachymenoides (Schmidt \& Walker, 1943) & CE-SO Pe & trans-Andean \\
\hline Philodryas trilineata (Burmeister, 1861) & No Ar & cis-Andean \\
\hline Philodryas varia (Jan, 1863) & NW Ar and W Bo & cis-Andean \\
\hline Philodryas viridissima (Linnaeus, 1758) & SO Co, Bo, NW-NO-NE-CE-SE Br, E EC, Gu, E Pe, Su, and SO Ve & cis-Andean \\
\hline
\end{tabular}

1977; Thomas \& Fernandes, 1996; Thomas \& Johnson, 1984; Thomas \& Di-Bernardo, 2001), D’Agostini (1998), Barrio et al. (1977), and Zaher (Zaher, 1999; Zaher et al., $2008,2009,2014)$. Nonetheless, a number of widely distributed and taxonomically complex entities with poorly assessed morphological variation await investigation, including, for example, P. aestiva, P. olfersii, P. patagoniensis, and P. psammophidea (Arredondo, 2012; Thomas, 1976; Zaher et al., 2008).

Several molecular phylogenetic studies incorporated a limited number of representatives of Philodryadini, and obtained conflicting hypotheses of relationships for the tribe (Cadle, 1984a, b, c; Grazziotin et al., 2012; Jenner \& Dowling, 1985; Machado, 1993; Maglio, 1970; Zaher, 1999; Zaher et al., 2009). Cadle (1984a) found that Philodryas was not related to Alsophis, as previously stated by Maglio (1970), but rather was more closely related to the South American genus Xenodon. Machado (1993), based on hemipenial evidence, allocated Oxybelis argenteus (Daudin, 1803) to the new xenodontine genus Xenoxybelis which, along with Pseudablabes agassizii (Jan, 1863), were considered by Zaher (1999) to share hemipenial characteristics with Philodryas. Lobo \& Scrocchi (1994) provided the first osteological phylogenetic analysis of Philodryas, based on representatives of 11 species. Thomas \& Fernandes (1996) further revised the morphological definition of Philodryas by including monotypic Platyinion Amaral, 1923 in the synonymy of Philodryas. According to Zaher (1999), Philodryas was paraphyletic and could be divided in two distinct lineages defined by their hemipenial morphology: the olfersii-group including Xenoxybelis; and the chamisso- nis-group. More recently, a series of molecularly oriented studies allowed a better understanding of supra-generic relationships within New World colubroid snakes, corroborating many of Zaher's (1999) previous morphological conclusions for that group (Vidal et al., 2000, 2010; Zaher et al., 2009). Subsequent molecular assessments that included species of the tribe Philodryadini invariably recovered the tribe as a monophyletic assemblage (Grazziotin et al., 2012; Pyron et al., 2011, 2013; Vidal et al., 2010; Zaher et al., 2018, 2019). Nevertheless, the sampled diversity of Philodryadini in these studies never exceeded slightly more than half of the known species of the tribe (Table 2).

Here, we provide a phylogenetic analysis based on a multilocus molecular dataset that incorporates representatives of $83 \%$ of all known species of Philodryadini. Our assessment requires a taxonomic revision to maintain monophyletic lineages.

\section{MATERIAL AND METHODS}

\section{Taxon sampling, DNA extraction, and sequencing}

We based our analyses on a molecular dataset comprising 33 terminals previously classified as Philodryadini and 59 additional colubroidean terminal taxa (Extended Data S1; see Supplementary Information at Figshare http://doi.org/10.6084/m9.figshare.13061516). We included representatives of the following five families (number of terminals in parenthesis): Colubridae (3), Sibynophiidae (2), Grayiidae (1), Natricidae (4) and 
Table 2. Species of Philodryadini (sensu lato) employed by the most recent molecular phylogenetic studies. $X^{A}=$ Species sampled for the first time in a molecular study.

\begin{tabular}{|c|c|c|c|c|c|c|c|c|c|}
\hline Species & $\begin{array}{c}\text { Zaher et al. } \\
(2009)\end{array}$ & $\begin{array}{c}\text { Vidal et al. } \\
\text { (2010) }\end{array}$ & $\begin{array}{c}\text { Pyron et al. } \\
\text { (2011) }\end{array}$ & $\begin{array}{c}\text { Grazziotin et al. } \\
\text { (2012) }\end{array}$ & $\begin{array}{c}\text { Figueroa et al. } \\
\text { (2016) }\end{array}$ & $\begin{array}{c}\text { Zaher et al. } \\
(2018)\end{array}$ & $\begin{array}{c}\text { Zaher et al. } \\
\text { (2019) }\end{array}$ & This study & Distribution \\
\hline P. aestiva & $x$ & $x$ & & $x$ & $x$ & $x$ & $x$ & $x$ & cis-Andean \\
\hline P. agassizii & $x$ & $x$ & $x$ & $x$ & $x$ & $x$ & $x$ & $x$ & cis-Andean \\
\hline P. argentea & $x$ & $x$ & & $x$ & $x$ & $x$ & $x$ & $x$ & cis-Andean \\
\hline P. arnaldoi & & & & & & & & $X^{A}$ & cis-Andean \\
\hline P. baroni & & $x$ & $x$ & $x$ & $x$ & $x$ & $x$ & $x$ & cis-Andean \\
\hline P. georgeboulengeri & & & $x$ & & $x$ & $x$ & $x$ & $x$ & cis-Andean \\
\hline P. chamissonis & & & & & $x$ & & & $X^{A}$ & trans-Andean \\
\hline P. erlandi & & & & & & & & $X^{A}$ & cis-Andean \\
\hline P. laticeps & & & & & & & & $X^{A}$ & cis-Andean \\
\hline P. livida & & & & & & & $x$ & $x$ & cis-Andean \\
\hline P. mattogrossensis & $x$ & $x$ & & $x$ & $x$ & $x$ & $x$ & $x$ & cis-Andean \\
\hline P. nattereri & & & $x$ & $x$ & $x$ & $x$ & $x$ & $x$ & cis-Andean \\
\hline P. olfersii & & $x$ & $x$ & $x$ & $x$ & $x$ & $x$ & $x$ & cis-Andean \\
\hline P. patagoniensis & $x$ & $x$ & $x$ & $x$ & $x$ & $x$ & $x$ & $x$ & cis-Andean \\
\hline P. psammophidea & & $x$ & & $x$ & $x$ & $x$ & $x$ & $x$ & cis-Andean \\
\hline P. simonsii & & & & & & & & $X^{A}$ & trans-Andean \\
\hline P. tachymenoides & & & & & & & & $X^{A}$ & trans-Andean \\
\hline P. trilineata & & & & & $x$ & $x$ & $x$ & $x$ & cis-Andean \\
\hline P. varia & & & & & & & $x$ & $x$ & cis-Andean \\
\hline P. viridissima & & $x$ & $X$ & $x$ & $X$ & $x$ & $X$ & $x$ & cis-Andean \\
\hline Total & 5 & 9 & 7 & 10 & 13 & 12 & 14 & 20 & \\
\hline
\end{tabular}

Dipsadidae (49). In order to provide a proper test for the monophyly of Philodryadini, we densely sampled within Dipsadidae by including representatives of the 12 tribes of Xenodontinae (31), of the subfamilies Carphophiinae (5) and Dipsadinae (11), and of the Asian genera Thermophis (1) and Stichophanes (1). Our sample of the genus Philodryas comprised all known species, with the exception of $P$. amaru Zaher et al., 2014, P. boliviana Boulenger, 1896, and $P$. cordata Donnelly \& Myers, 1991, which are known from only a few type specimens (Donnelly \& Myers, 1991; Wallach et al., 2014; Zaher et al., 2014). We did not obtain sequences from Ditaxodon Hoge 1958, the other genus of Philodryadini, also known from only a few specimens (Thomas et al., 2006). We rooted our resulting trees on Natricidae, following the topology presented in Zaher et al. (2019).

We extracted DNA from liver, muscle, scales, or shed skins, using Phenol-Chloroform method or PureLink ${ }^{\circledR}$ Genomic DNA kit (ThermoFisher, MA, USA). We amplified fragments via polymerase chain reaction (PCR) for three nuclear (bdnf, c-mos and nt3) and three mitochondrial (12S, cox 1 and cytb) genes. The primer sets and protocols used in the PCR were based in the following studies: Noonan \& Chippindale (2006) for bdnf and $n t 3 ;$ Zaher et al. (2009) for $12 \mathrm{~S}$ and c-mos; Grazziotin et al. (2012) for cytb; Graboski et al. (2018) for cox1.

We used standard PCR protocols with modifications to improve the efficiency as follows: adding $10 \%$ of Trehalose 100 for $125, c y t b$, and cox 1 , and $0.4 \%$ of Triton 100 for cmos, bdnf, and $n t 3$. We amplified both strands and employed an annealing temperature of $54^{\circ} \mathrm{C}$ for $12 \mathrm{~S}$, $56^{\circ} \mathrm{C}$ for bdnf and $\mathrm{cmos}$, a touch down cycle of $58-46^{\circ} \mathrm{C}$ with final annealing of $48^{\circ} \mathrm{C}$ for $n t 3$, and a touch down cycle of $60-50^{\circ} \mathrm{C}$ with final annealing of $54^{\circ} \mathrm{C}$ for cytb and cox1. All PCR products were purified with the Exo-Sap (exonuclease and shrimp alkaline phosphatase) protocol and the sequences were processed at the Laboratório de Biologia Genômica e Molecular from the Pontifícia Universidade Católica do Rio Grande do Sul (PUCRS), Laboratório de Toxinologia Aplicada (LETA) from Instituto Butantan, and Macrogen (Seul, Korea). We sequenced and checked both strands, and when necessary the chromatographs were edited manually. We performed the assembly and generated the consensus sequences using Geneious 6.1.8 (http://www.geneious.com, Kearse et al., 2012).

\section{Phylogenetic analyses}

We generated 179 new sequences and obtained other 300 sequences from GenBank to build our molecular matrices (Extended Table S1). Our concatenated dataset comprised a total of 4,433 base pairs of aligned sequences, including 510 from 12S, 1,107 from cox 1, 997 from $c y t b, 710$ from bdnf, 586 from cmos, and 523 from nt3 (Extended Data S1).

We used MAFFT 1.3.6 (Katoh et al., 2005), as implemented in Geneious, to align all sequences. The rRNA gene $12 \mathrm{~S}$ was aligned under the E-INS-i algorithm, while the protein-coding genes bdnf, c-mos, cox 1, cytb, and nt3 were aligned under the G-INS-i algorithm. We used default parameters for gap opening and extension. All protein-coding genes were visually checked using Geneious to verify if all sequences follow the correct reading frame. We concatenated our sequences using Sequence Matrix 1.8 (Vaidya et al., 2011).

We used PartitionFinder 2 (Lanfear et al., 2016) to choose the models of molecular evolution for our database and employed two different analyses. In the 
first analysis, we used the Akaike Information Criterion with correction (AICc), allowing the selection of models of molecular evolution implemented in RAxML 8.2.3 (Stamatakis, 2014), using unlinked branch lengths and the greedy search option. We only allowed PartitionFinder to select GTR model with or without GAMMA, preventing models with correction for proportion of invariant sites, as suggested in the RAxML manual. In the second analysis, we used the Bayesian Information Criterion (BIC), allowing selection of all models of molecular evolution implemented in MrBayes 3.2.5 (Ronquist et al., 2012). We preliminarily defined 16 partitions for our concatenated matrix, treating the rRNA gene (12S) as a separate partition and partitioning all five protein-coding genes by their codon positions. The results of PartitionFinder are provided in Extended Table S2.

We conducted a maximum likelihood (ML) analysis in RAXML using the algorithm that conducts a rapid bootstrap analysis and searches for best scoring $M L$ tree in the same run (option $-f a$ ), and defined 1,000 bootstrap iterations to estimate branch support (BS). We also conducted a Bayesian Inference phylogenetic analysis (BI) in MrBayes 3.2.5 with four independent runs, 20 million generations, sampling trees every 1,000 generations. We used Tracer 1.7.1 (Rambaut et al., 2018) to check the effective sample size (ESS) and trace convergence to set the burn-in. We estimated Bayesian posterior probability (PP) after burn-in. Both ML and BI phylogenetic analyses were carried out on the CIPRES Science Gateway (http://www.phylo.org, Miller et al., 2010). Robustness of clades were checked using both BS and PP support values.

When defining and naming evolutionary lineages retrieved in our analyses, we followed the Taxon Naming Criteria (TNCs) suggested by Vences et al. (2013), avoiding taxonomic instability and inadequate classification schemes of non-monophyletic groups.

\section{RESULTS}

The ML and BI tree topologies showed very similar higher-level relationships, with Colubridae, Natricidae, Sibynophiidae, and Dipsadidae being all recovered as monophyletic lineages with robust to unambiguous support values (Fig. 1; Extended Figs. S1-S2). Only the position of Grayiidae varied, being retrieved with ambiguous support as the sister group of Colubridae in the ML tree and as the sister group of a clade formed by Colubridae and Sibynophiidae in the BI tree (Fig. 1; Extended Fig. S2). Within Dipsadidae, the Asian Thermophis baileyi and Sticophanes ningshaanensis were retrieved as two successive sister taxa to the New World dipsadids in both $\mathrm{ML}$ and $\mathrm{BI}$ topologies (Fig. 1). Within the New World radiation, North American Carphophiinae was retrieved as monophyletic only in the ML tree, with no statistical support. Subfamilies Dipsadinae and Xenodontinae as well as tribes Imantodini and Dipsadini were retrieved as robustly supported clades in both $\mathrm{ML}$ and $\mathrm{BI}$ topologies (Fig. 1; Extended Fig. S2).
Considering both $\mathrm{ML}$ and $\mathrm{BI}$ analyses, only the tribes Philodryadini and Echinantherini within Xenodontinae were not recovered as monophyletic groups. All other tribes represented by more than one terminal were recovered with strong to unambiguous support values in both analyses, but relationships between them were not supported by high values of support, with the BI tree resulting in a large polytomy (Fig. 1; Extended Fig. S2).

The traditionally recognized tribe Philodryadini was split into two monophyletic lineages in both analyses-a central Andean clade and a southern and cis-Andean clade-with Tropidodryadini nested between them, robustly positioned in both analyses as the sister group of the southern and cis-Andean radiation of Philodryadini (Fig. 1; Extended Figs. S1-S2). The central Andean clade was retrieved as the sister group of the clade formed by Tropidodryadini + southern and cis-Andean Philodryadini only in the ML analysis, with low values of $\mathrm{BS}$, while in the $\mathrm{BI}$ analysis it was recovered in a polytomy along with several other clades (Fig. 2).

The central Andean clade was composed by the strictly Andean species Philodryas simonsii and Philodryas tachymenoides. These represented a distinct evolutionary lineage from the southern and cis-Andean clade of Philodryadini. Phylogenetic affinities exhibited within southern and cis-Andean radiation were the same in both $\mathrm{ML}$ and $\mathrm{BI}$ topologies (Extended Figs. S1-S2).

Phylogenetic relationship within the southern and cis-Andean radiation revealed the presence of two main evolutionary lineages: Clades $A$ and $B$ in Fig. 2. Clade $A$ was recovered with low values of support, and contained the Common Green Racer $P$. viridissima and the rare $P$. Iaticeps forming Subclade A1, and the South American Vine Snakes $P$. argentea and $P$. georgeboulengeri composing Subclade A2, both with robust and unambiguous support values (Fig. 2). The remaining species of Philodryas grouped in the robustly supported Clade B, with $P$. nattereri placed as the sister group of five successive, robustly to unambiguously supported subclades, as follow: Subclade B2 composed by P. mattogrossensis and P. erlandi; Subclade B3 including the Southern Andean $P$. chamissonis as sister of the Argentinian species P. baroni and P. trilineata; Subclade B4 formed by the South American Green Racers $P$. olfersii and $P$. arnaldoi; Subclade B5 composed only by the Brazilian Green Racer P. aestiva; and Subclade B6 formed by the "patagoniensis group" composed by P. agassizii, P. livida, P. patagoniensis, P. psammophidea, and P. varia (Fig. 2). Within the "patagoniensis group", $P$. varia and $P$. patagoniensis on the one hand, and P. psammophidea nested with $P$. livida + $P$. agassizii, on the other hand, grouped together as sister clades, the former lacking statistical support values while the latter was robustly supported.

Our results indicate that the traditional taxonomic arrangement for Philodryadini does not reflect the topology of the phylogenetic tree. To determine a more accurate classification based on monophyletic groups, we propose below a revised classification for the tribe based on our phylogenetic results and on a diagnostic set of morphological characters. 

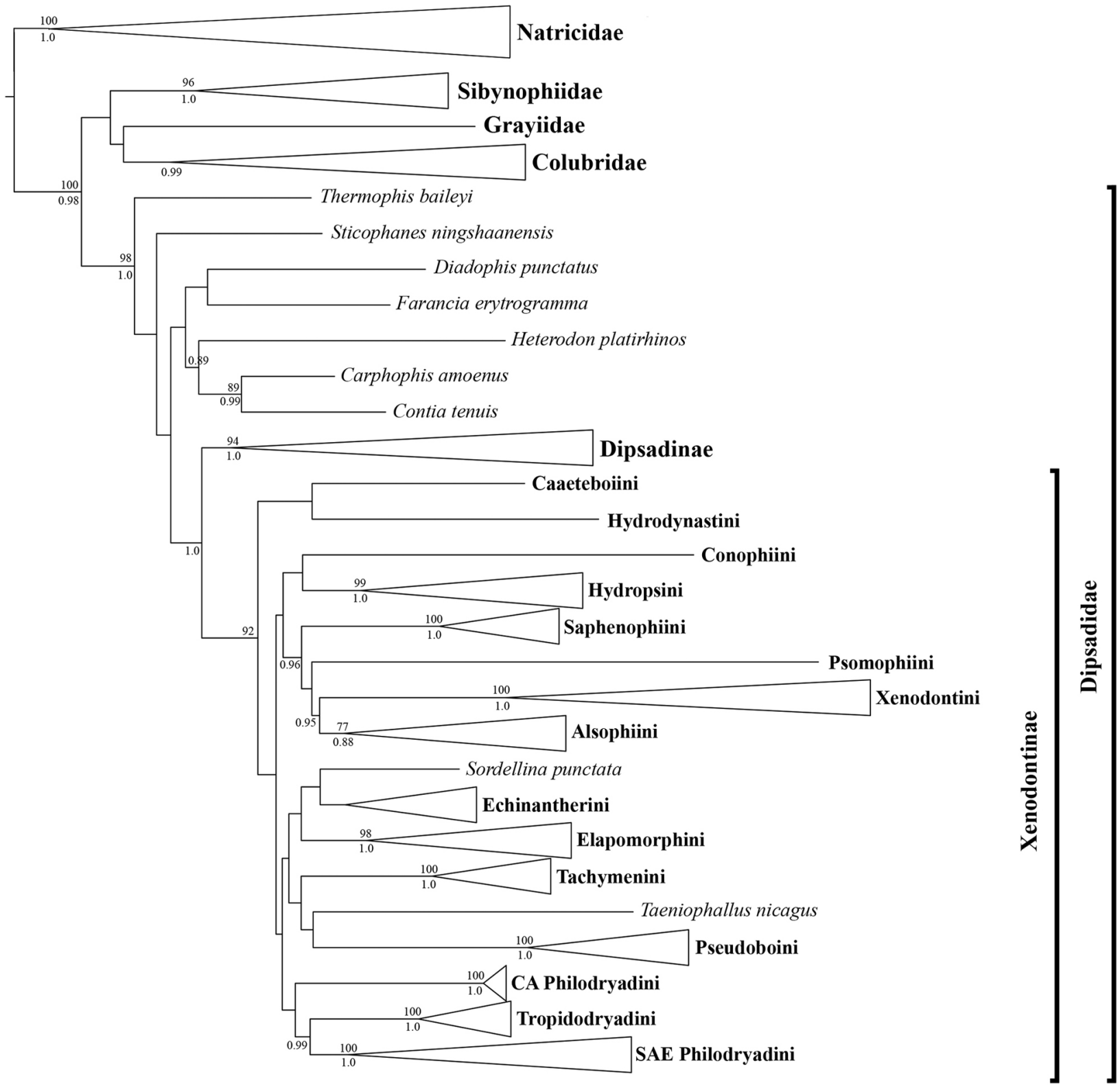

Figure 1. Maximum likelihood (ML) tree of Dipsadidae estimated using RAxML. Summary tree with collapsed terminals showing higher-level relationships. Numbers above and below branches indicate bootstrap and posterior probability support values, respectively. Bootstrap values below $70 \%$ and posterior probabilities below $85 \%$ are not shown. Abbreviations: $C A=$ central Andean; SAE = southern and cis-Andean.

\section{Systematic Account}

\section{Tribe Philodryadini Cope, 1886}

Type-genus: Philodryas Wagler, 1930 by original designation and monotypy.

Type species: Coluber olfersii Lichtenstein, 1823.

Content: Chlorosoma Wagler, 1830 resurrected; Ditaxodon Hoge, 1958; Philodryas Wagler, 1830; Xenoxybelis Machado, 1993 resurrected.

Diagnosis: Members of the tribe Philodryadini can be distinguished from the other xenodontine genera by the following combination of characters: hemipenis bilobed, semicalyculate and semicapitate; large body calyces cov- ering both medial and distal portions of the asulcate side of the hemipenial body and lobes (Figs. 3-4); maxillary dentition diacranterian and opisthoglyphous, with a deep groove that opens laterally.

Geographical distribution: most of the Cis-Andean portion of South America, from southern Colombia, Venezuela, Guianas, Ecuador, Peru, Brazil, Bolivia, Paraguay, Uruguay, and Argentina, and in the TransAndean portion of the southern Andes in Chile.

\section{Genus Philodryas Wagler, 1930}

Type species: Coluber olfersii Lichtenstein, 1823.

Synonyms: See Wallach et al. (2014) for a complete list of generic synonyms. 
Content (16 species): Philodryas aestiva (Duméril, Bibron \& Duméril, 1854), Philodryas agassizii (Jan, 1863), Philodryas arnaldoi (Amaral, 1932), Philodryas boliviana Boulenger, 1896, Philodryas baroni Berg, 1895, Philodryas chamissonis (Wiegmann, 1835), Philodryas cordata Donnelly \& Myers, 1991, Philodryas erlandi Lönnberg, 1902, Philodryas livida (Amaral, 1923), Philodryas mattogrossensis Koslowsky, 1898, Philodryas nattereri Steindachner, 1870, Philodryas olfersii (Lichtenstein, 1823), Philodryas patagoniensis (Girard, 1858), Philodryas psammophidea Günther, 1872, Philodryas trilineata (Burmeister, 1861), and Philodryas varia (Jan, 1863).

Diagnosis: Philodryas can be distinguished from the other Philodryadini genera by the following combination of characters: Hemipenial body much longer than the lobes (more than twice the length), with the asulcate side of the hemipenial body covered with two parallel rows of enlarged body calyces on most or all its surface (Figs. 3-4); dentary teeth equal in size (significantly enlarged dentary teeth in Ditaxodon); ventral scales smooth (keeled in Chlorosoma); buccal epithelium cream or white.

Geographical distribution: Same as the tribe.

Etymology: Donnelly \& Myers (1991:46) argued convincingly that the meaning of the generic name Philodryas is "friendly tree nymph," being a feminine gender resulting from the combination of the Greek words Philos- (noun, $\varphi \check{i} \lambda$ os, meaning "friend or friendly") and -Dryas (noun, $\Delta \rho \breve{\alpha} \breve{s}$, meaning "tree nymph").

\section{Genus Chlorosoma Wagler, 1830 resurrected}

Type species: Coluber viridissimus Linneaus, 1758, by original designation and monotypy.

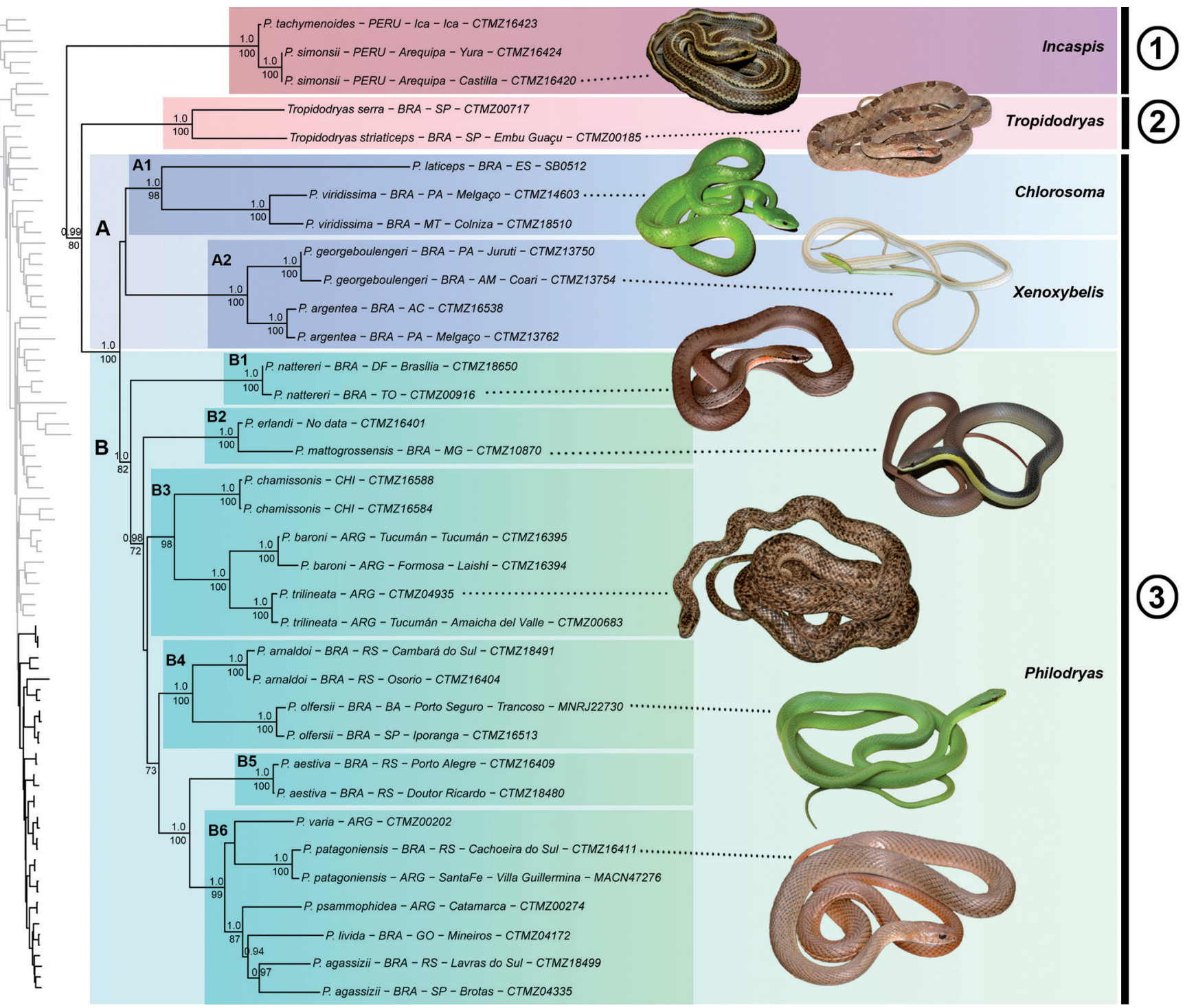

Figure 2. Maximum likelihood (ML) tree estimated using RAxML, showing only the relationships of Incaspidini (1), Tropidodryadini (2), and Philodryadini (3). Terminal names on the left are presented following nomenclature in current literature, while generic and tribal arrangements on the right show our changes in the classification of Philodryadini. Numbers above and below branches indicate posterior probability and bootstrap support values, respectively. Bootstrap values below $70 \%$ and posterior probabilities below $85 \%$ are not shown. 


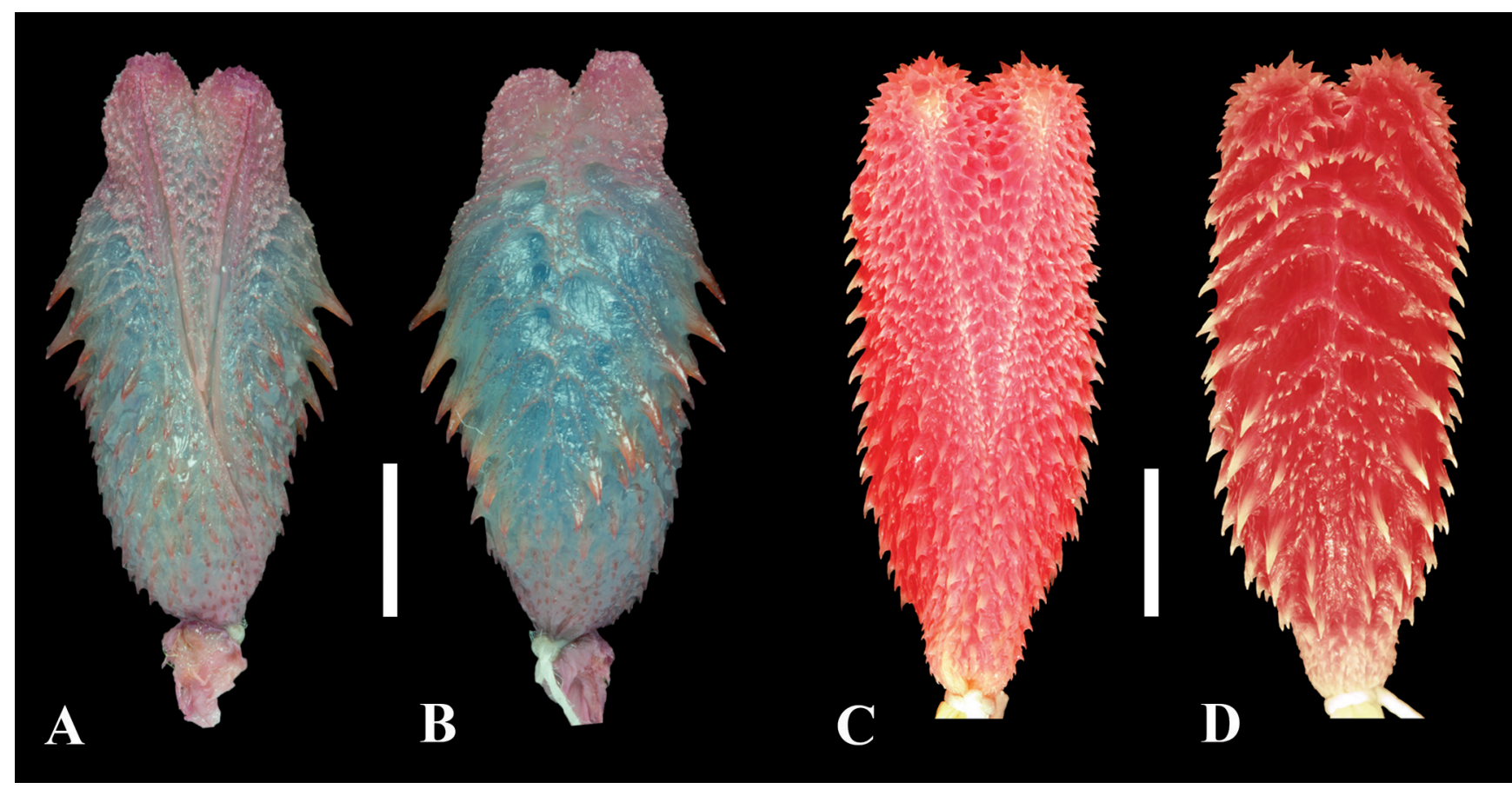

Figure 3. Hemipenes of Chlorosoma viridissimum (MUSM 2403) in A and B, and Incaspis amaru (FHG0 4749) in C and D. Photographs in A and C are in sulcate views, and photographs in B and D are in asulcate views. Scale bars: $5 \mathrm{~mm}$.

Content: (two species) Chlorosoma laticeps (Werner, 1900) new combination; Chlorosoma viridissimum (Linneaus, 1758).

Diagnosis: Chlorosoma can be distinguished from the other genera of Philodryadini by the following combination of characters: ventral and subcaudal scales strong- ly angulated laterally (keeled); ontogenetic change in color pattern, with juveniles exhibiting dark chevrons throughout the body dorsum and adults changing to a homogeneously green dorsum; ventral surface with a yellow, white or cream gular region (excluding infralabial scales) and green venter and tail; short hemipenes with reduced lateral enlarged spines.

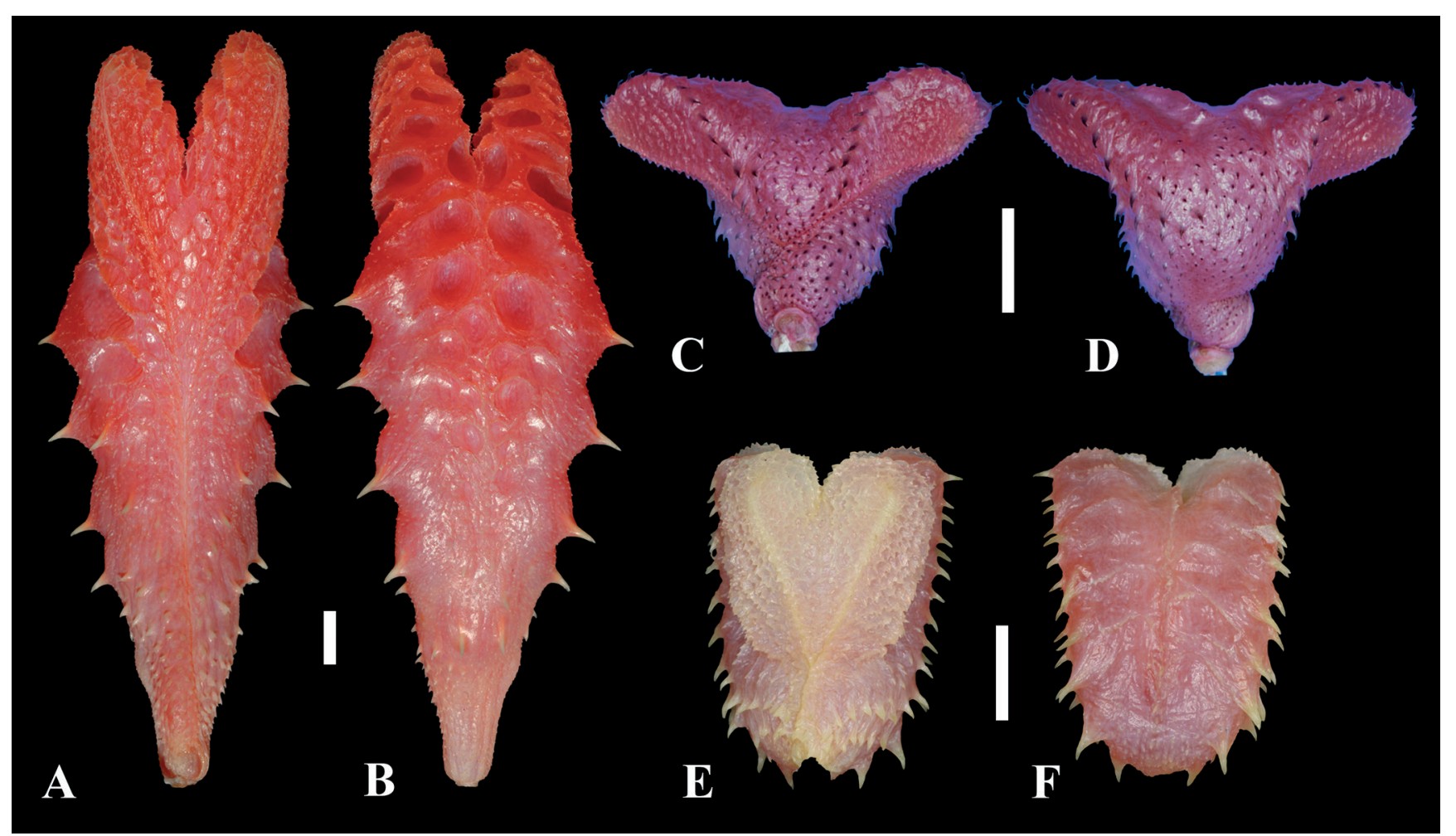

Figure 4. Hemipenis of Philodryas chamissonis (MNHN 3807) in A and B, Tropidodryas serra (MNRJ 7354) in C and D, and Xenoxybelis argenteus (BMNH 1994.7000) in $E$ and $F$. Photographs in $A, C$, and $E$ are in sulcate views, and photographs in B, D, and $F$ are in asulcate views. Scale bars: $5 \mathrm{~mm}$. 
Geographical distribution: Chlorosoma viridissimum occurs in the eastern lowlands of northern and central South America, including Amazonian forests of Colombia, Venezuela, Suriname, Guyanas, Ecuador, Peru, Brazil, and Bolivia. In Brazil this species also inhabits the ecotone between Amazonian and Cerrado biomes, and a single population is present in the lowland forest of the Atlantic coast of the Bahia state. Chlorosoma laticeps shows a disjunct distribution pattern, with records from central Bolivia in Santa Cruz and Cochabamba departments, and Southeastern Brazil in Espírito Santo, Minas Gerais and Santa Catarina states (Zaher et al., 2008).

Etymology: The generic name is neuter, being a combi-

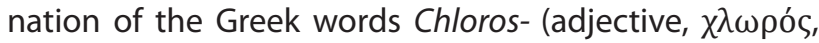
meaning "bright green") and -soma (noun, $\sigma \tilde{\omega} \mu \alpha$, meaning "body"), in reference to the overall bright green coloration of the body in these species. The gender of the name Chlorosoma is grammatically neuter (Amaral 1929a, b, c, 1932) since the meaning given by Wagler (1830) was of a "green snake." Therefore, the correct spelling for the type species of the genus is Chlorosoma viridissimum.

Comment: Wagler (1830) used the same contribution to erect the genera Chlorosoma and Philodryas for the species Coluber viridissimus Linneaus 1758 and Coluber olfersii Liechtenstein 1823, respectively. Shortly after, Günther (1858), redefined the genus Philodryas to allocate $P$. aestivus, P. dorsalis (= Ialtris), P. goudotii (=Ithycyphus), P. olfersii, $P$. serra (= Tropidodryas), Philodryas schottii (= patagoniensis), and Philodryas viridissimus. Considering that Wagler (1830) described Chlorosoma before Philodryas on page 185, Amaral (1929a, b, 1932) decided to apply the Principle of Priority and assigned all species of Philodryas known at the time to the genus Chlorosoma (i.e., C. aestivum, C. arnaldoi, C. burmeisteri (= trilineata), C. mattogrossense, C. olfersii, C. schottii (= patagoniensis), C. psammophideum, and C. viridissimum). However, Parker (1932) pointed out that Günther's (1858) generic classification using the name Philodryas for these species had priority under the Principle of the First Reviser (Art. 24.2.2, ICZN 1999). Thus, the genus Chlorosoma is available for the recovered evolutionary lineage including Philodryas viridissima and Philodryas laticeps.

\section{Genus Xenoxybelis Machado, 1993 resurrected}

Type species: Coluber argenteus Daudin, 1803, by original designation.

Synonyms: Oxybelis Wagler, 1830; Philodryas Wagler, 1830.

Content: (two species) Xenoxybelis argenteus (Daudin, 1803); Xenoxybelis boulengeri (Procter, 1923) species name revalidated.

Diagnosis: Xenoxybelis can be distinguished from the other genera of Philodryadini by the following combination of characters: markedly elongated snout, forming an acuminated and sharp head shape; large number of prediastemal maxillary teeth (16-21), followed by one or two grooved postdiastemal teeth; short heart-shaped hemipenes with a well-defined papillate longitudinal crest, formed by the confluence of the body calyces, that runs medially in the asulcate surface; lateral surfaces of hemipenes covered with two to four rows of well-developed enlarged lateral spines (Fig. 4).

Geographical distribution: Both species occur in the Amazonian region, from Colombia and Guianas to Bolivia and Paraguay (Cunha \& Nascimento, 1978; Prudente et al., 2008).

Etymology: The generic name of the South American Vine snake Xenoxybelis is formed by the Greek words

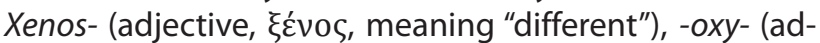

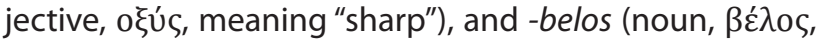
meaning "dart"), in reference to their external similarity with the unrelated Neotropical Vine snake genus Oxybelis Wagler, 1830.

Comment: Zaher et al. (2009) and Grazziotin et al. (2012) placed Xenoxybelis and Pseudablabes under the synonymy of Philodryas. With this nomenclatural act, Philodryas boulengeri Werner, 1909 and Philodryas boulengeri (Procter, 1923) became secondary homonyms (Grazziotin et al., 2012), resulting in the proposition of the new replacement name georgeboulengeri for the latter species. According to our phylogenetic results, returning Philodryas georgeboulengeri (Procter, 1923) to the revalidated genus Xenoxybelis eliminates the homonymy. Therefore, we revalidate the species name Xenoxybelis boulengeri (Procter, 1923).

\section{Tribe Incaspidini, New tribe}

Type-genus: Incaspis Donoso-Barros, 1974, by original designation, resurrected.

Type species: Philodryas simonsii Boulenger, 1900, by original designation.

Content: Incaspis Donoso-Barros, 1974, resurrected.

Diagnosis: Members of the tribe Incaspidini can be distinguished from the other genera of Xenodontinae by the following combination of characters: maxillae diacranterian and opisthodont, with ungrooved postdiastemal teeth; hemipenes significantly longer than wide (up to 3.5 times), with large shallow body calyces on upper half of the asulcate region, numerous small-sized lateral enlarged spines, and a well-defined constriction in the proximal region of the hemipenial body (Fig. 3).

Geographical distribution: Andean region in Southern Ecuador, Peru and possibly northern Chile.

Etymology: The singular of the genitive case of the second part of the tribe name (aspis) is aspides. Therefore, the correct spelling of the new tribe is Incaspidini. 


\section{Genus Incaspis Donoso-Barros, 1974, resurrected}

Type species: Philodryas simonsii Boulenger, 1900, by original designation.

Content: (three species) Incaspis amaru (Zaher, Arredondo, Valencia, Arbeláez, Rodrigues \& AltamiranoBenavides, 2014) new combination; Incaspis simonsii (Boulenger, 1900) new combination; Incaspis tachymenoides (Schmidt \& Walker, 1943) new combination.

Diagnosis: Same as the tribe.

Geographical distribution: Same as the tribe.

Etymology: The genus name is a combination of the Quechua word Inca (adjective, meaning royalty) and the

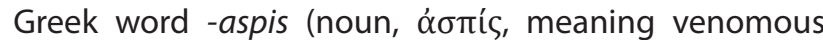
snake), in reference to the Andean region where the Inca Empire was established.

Comment: The generic name Incaspis was erected by Donoso-Barros (1974) to describe Incaspis cercostropha, which, along with Dromicus angustilineatus Schmidt \& Walker, 1943 and Dromicus inca Schmidt \& Walker, 1943 , were shortly after placed under the synonymy of Philodryas simonsii Boulenger, 1900 by Thomas (1977). Although no tissue samples were available from Incaspis amaru, we allocate this species in the genus Incaspis since it shares all the diagnostic features listed above for the genus and the tribe. The occurrence of I. amaru in the same biogeographical region as I. simonsii and I. tachymenoides also supports its allocation in the tribe, which seems to be an endemic component of Central Andes.

\section{DISCUSSION}

As in most recent systematic studies, our analyses retrieve the highly diverse family Dipsadidae with strong support (Figueroa et al., 2016; Grazziotin et al., 2012; Pyron et al., 2011; Vidal et al., 2010; Zaher et al., 2009, 2018, 2019). Notwithstanding, our results from both $\mathrm{ML}$ and $\mathrm{BI}$ support the monophyly of most previously hypothesized xenodontine tribes (Zaher et al., 2009; Grazziotin et al., 2012), but do not recover well-established relationships between them (Fig. 1). One notable exception is the robustly supported clade formed by the Tropidodryadini and the redefined tribe Philodryadini (Figs. 1-2). Historically, a close relationship between members of the tribes Philodryadini and Tropidodryadini has already been advocated by several authors (Amaral, 1937; Dowling \& Duellman, 1978; Ferrarezzi, 1994; Günther, 1858; Lobo \& Scrocchi, 1994; Pyron et al., 2011; Vidal et al., 2010; Zaher et al., 2012, 2018, 2019; but see Grazziotin et al., 2012 and Pyron et al., 2013). However, none of these studies had adequate taxon sampling within Philodryas, reaching only a maximum of $58 \%$ of the known diversity of the tribe Philodryadini and lacking representation of the Central Andean species (e.g., Pyron et al., 2011; Figueroa et al., 2016) (Table 2). Consequently, Pyron et al. (2011) retrieved a non-monophyletic Philodryadini, with $P$. viridissima clustering with Tomodon and Hydropsini instead of the other species of Philodryas. In contrast, Figueroa et al. (2016) recovered a highly supported clade composed by $P$. chamissonis, $P$. trilineata, and the genera Xenopholis, Hydrodynastes, and Caaeteboia, while the remaining species of Philodryas grouped with Sordellina punctata and the Echinantherini. As pointed out by these authors, their topology most likely resulted from the absence of homologous molecular markers for these lineages, as they only used sequences for the mitochondrial gene nd4 for $P$. chamissonis and $P$. trilineata, and a combination of $12 \mathrm{~S}, 16 \mathrm{~S}, \mathrm{bdnf}, \mathrm{cmos}$, and cytb for the remaining species of Philodryas.

Pyron et al.'s (2011) and Figueroa et al.'s (2016) unexpected phylogenetic results highlight the necessity of a comprehensive taxon sampling to resolve the phylogenetic affinities within this group. Here, we expand both gene and taxon samplings for the group, reaching $83 \%$ of the known diversity of the former composition of Philodryadini. We also added for the first time critical central and Southern Andean lineages of Philodryas and the rare species $C$. laticeps (Table 2). Surprisingly, our results reveal that the central Andean species-represented by Incaspis simonsii, I. tachymenoides, and I. amaru-are a distinct lineage of Andean endemics while the genus Tropidodryas appears in a robustly supported clade as the sister group of all other southern and cis-Andean species of Philodryas (Fig. 2). Resurrection of Incaspis for the central Andean species, with its allocation in the new tribe Incaspidini, reflects their distinctiveness and uncertainties regarding their phylogenetic relationships within Xenodontinae, while highlighting the closer affinities revealed by the Tropidodryadini and the southern and cis-andean Philodryas (Fig. 1; Extended Fig. S2). Therefore, our results restrict Philodryadini to a widespread lineage of mostly lowland cis-Andean species, except for the trans-Andean $P$. chamissonis, which occurs in both low and high elevations throughout southern Andean region (Sallaberry-Pincheira et al., 2011). Further, Incaspidini represents a distinct lineage of endemic species mainly found in highlands of the central Andes of Ecuador and Peru.

Historically, a certain confusion has existed around the systematics of the species here allocated in the tribe Incaspidini, mainly because their characteristic ungrooved postdiastemal maxillary teeth led several authors to associate them with the opisthodont genera Alsophis, Dromicus, and Leimadophis (Amaral, 1929a, b, c; Parker, 1932; Peters, 1960; Thomas, 1977). Additionally, $P$. chamissonis also retains ungrooved postdiastemal (opisthodont) maxillary teeth, although its hemipenial morphology characterized by a very long hemipenial body and moderately long lobes closely approaches the one of the larger mainland cis-andean species $P$. nattereri, P. psammophidea, P. baroni, and P. trilineata (Zaher, 1999). Philodryas chamissonis was viewed accordingly as a morphological intermediate between the central Andean 
opisthodont and the cis-Andean opisthoglyph species of Philodryas (Thomas, 1976; Lobo \& Scrocchi, 1994; Zaher, 1999). However, our results show that the opisthodont condition found in the Incaspidini and in P. chamissonis owes to convergence rather than being a shared derived characteristic (Zaher et al., 2014).

The southern and cis-Andean radiation is recovered in our analyses as two sister Clades A and B (Fig. 2). The topology provides the basis for the resurrection of Chlorosoma and Xenoxybelis, for the Common Green Racers and South American Vine snakes, respectively. Xenoxybelis corresponds to a genus of highly specialized arboreal snakes that have been traditionally considered to be morphologically distinct from all the other Philodryadini. However, their uncertain position within the group led to its synonymization with the latter as a way to reinstate a monophyletic definition for the group (Grazziotin et al., 2012). Our expanded taxonomic coverage recovers a more stable phylogenetic hypothesis that allows the recognition of its morphological differences. Similarly, Chlorosoma corresponds to a vestigial clade of arboreal snakes that also harbors morphological differences from Philodryas (Clade B), including a short hemipenes and laterally keeled ventral scales.

The redefined genus Philodryas includes now 14 species that are retrieved in our analyses in six strongly supported subclades (Subclades B1 to B6 in Fig. 2). Subclades B1 and B2 include Philodryas nattereri and $P$. erlandi $+P$. mattogrossensis, respectively, two successive sister groups to the remaining Subclades B3-B6. Subclades B1 and B2 include species that occur throughout the open biomes of Brazil, Bolivia, Paraguay, and Argentina (Nogueira et al., 2019), reinforcing the view that cis-Andean Racers of the genus Philodryas originated in open areas in South America and only later occupied forested biomes, such as the Atlantic and Amazonian forests. Species from Subclade B2 have a unique coloration pattern of gradual change from anterior green or yellow to reddish brown in the rest of the body and tail (Cacciali et al., 2016; Thomas, 1976). This appears to represent a synapomorphic trait for this subclade.

Subclade B3 includes $P$. chamissonis, $P$. baroni, and $P$. trilineata, and it corresponds to a group of racers restricted to the southern part of the continent, with $P$. chamissonis reaching as a single dispersal event the eastern part of southern Andes. According to Thomas (1976) and Lobo \& Scrocchi (1994), P. baroni, and P. trilineata are sister species, a hypothesis corroborated in our analysis.

Subclades B4, B5, and B6 include the commonest species of the genus, and these occur mostly in open and forested areas of the continent, east of the Andes and south of the Amazonian basin. The only exception is $P$. olfersii, whose range extends to parts of the Amazonian biome. Subclades B4 and B5 include the southern and southeastern Atlantic forest endemics $P$. aestiva and $P$. arnaldoi, and widespread $P$. olfersii; all three occur mainly in forested areas in South America.
Species in Subclade B6 inhabit both forested and open biomes. In this subclade, P. varia occurs in northern Argentina and Bolivia, while P. patagoniensis inhabits the southern and eastern parts of the continent, from northern Pará and Tocantins to Chubut in southern Argentina. In contrast, P. psammophidea, P. livida, and P. agassizi occur in the open biomes throughout the central and southern parts of the continent.

Redefined Philodryadini contains species with high relevance in public health (Sánchez et al., 2014; Weinstein et al., 2011). Records of envenomation exist for several species, including lethal cases for humans (Da Rocha et al., 2006; Weinstein et al., 2013). Philodryas has opisthoglyphous dentition, a venom delivery apparatus, and gland secretions containing venomous proteins and toxins (Modahl et al., 2016; Urra et al., 2015). This genus of South American opisthoglyphous snakes is responsible for most of the non-front fanged envenomations (Oliveira et al., 2017). Because most studies focusing on venom and envenomation of Philodryas were developed without a robust evolutionary context (Acosta et al., 2003; Da Rocha et al., 2006), they likely bypassed issues on intra and inter-specific variation and phylogenetic structure within species groups. Our phylogenetic hypothesis provides a more accurate evolutionary framework that will lead to a better understanding of venom variation and diversification in that group.

\section{AUTHORS' CONTRIBUTIONS}

JCA and $\mathrm{HZ}$ conceived the research project. JCA gathered the molecular data and performed the analyses; FGG contributed to the molecular analyses; JCA, $\mathrm{HZ}$, and FGG wrote the manuscript; GJS, MTR, and SLB contributed intellectually to the project, revised and discussed the text; $\mathrm{HZ}$ funded and supervised the research project.

\section{ACKNOWLEDGMENTS}

We are in dept with the curators and institutions staff who granted us access to the samples for obtention of molecular evidence. We thank J. Battilana for her help during acquisition of molecular data. We thank F. Curcio and L.J. Vitt for providing photographs of $P$. nattereri, $X$. boulengeri and $P$. olfersii used in Fig. 2 . We are grateful for the comments from two reviewers whose suggestions improved this manuscript. This study was financed in part by the Coordenação de Aperfeiçoamento de Pessoal de Nível Superior - Brasil (CAPES) - Finance Code 001. FGG was supported by FAPESP (grants 2012/08661-3 and 2016/13469-5). HZ, MTR, and SLB are grateful to Conselho Nacional de Desenvolvimento Científico e Tecnológico (CNPq) for continuing financial support. SLB and MTR were supported by FAPERGS and FAPESP (grants 2003/10335-8 and 2011/50146-6), respectively. This study was funded by Fundação de Amparo à Pesquisa do Estado de São Paulo (FAPESP grants 2011/50206-9 and 2016/50127-5) to HZ. 


\section{REFERENCES}

Acosta, 0.; De Vila, I.I.; Peichoto, M.E.; Maruñak, S.; Ruíz, R.; Teibler, P.; Gay, C. $\&$ Rey, I. 2003. Edematogenic and myotoxic activities of the Duvernoy's gland secretion of Philodryas olfersii from the north-east region of Argentina. Biocell, 27: 363-370.

Amaral, A. 1929a. Valor systematico de várias formas de ophidios neotropicos. Estudo sobre os ophidios neotropicos XVII. Memórias do Instituto Butantan, 4:3-67.

Amaral, A. 1929b. Lista remissiva dos ophidios do Brasil. Contribuição ao conhecimento dos ophidios do Brasil IV. Memórias do Instituto Butantan 4: 69-125.

Amaral, A. 1929c. Lista remissiva dos ophidios da região neotropica. Estudo sobre ophidios neotropicos XVIII. Memórias do Instituto Butantan, 4: 127-271.

Amaral, A. 1932. Contribuição ao conhecimento dos ofídios do Brasil. VI. Uma nova espécie de colubrideo opisthoglypho, do genero Chlorosoma Wagler, 1930. Memórias do Instituto Butantan, 7: 99-101.

Amaral, A. 1937. Contribuição do conhecimento dos ophidios do Brasil. 9. Nova especie de colubrideo opisthoglypho confundivel com Philodryas serra (Schlegel 1837). Memórias do Instituto Butantan, 11: 205-212.

Arredondo, J.C. 2012. Revisão taxonômica do complexo Philodryas olfersii (Lichtenstein 1823) (Serpentes: Dipsadidae). Master Dissertation, Universidade de São Paulo, São Paulo, SP. Brazil.

Barrio, A.; Laurent, R.F. \& Thomas R.A. 1977. The status of Philodryas subcarinatus Boulenger (Reptilia, Serpentes, Colubridae). Journal of Herpetology, 11(2): 230-231.

Cacciali, P.; Cabral, H.; Ferreira, V.L. \& Köhler, G. 2016. Revision of Philodryas mattogrossensis with the revalidation of $P$. erlandi (Reptilia: Squamata: Dipsadidae). Salamandra, 52(4): 293-305.

Cadle, J.E. 1984a. Molecular systematics of Neotropical xenodontine snakes: I. South American xenodontines. Herpetologica, 40: 8-20.

Cadle, J.E. 1984b. Molecular systematics of Neotropical xenodontine snakes: II. Central American xenodontines. Herpetologica, 21-30.

Cadle, J.E. 1984c. Molecular systematics of xenodontine colubrid snakes. III. Overview of xenodontine phylogeny and the history of New World snakes. Copeia, 1984: 641-652.

Cunha, 0. \& Nascimento, E.F. 1978. Ofidios da Amazonia. X. - As cobras da região leste do Pará. Publicações Avulsas Museu Paraense Emilio Goeldi, 31: 1-218.

Da Rocha, M.; Paixão-Cavalcante, D.; Tambourgi, D.V. \& Furtado, E.M. 2006. Duvernoy's gland secretion of Philodryas olfersii and Philodryas patagoniensis (Colubridae): Neutralization of local and systemic effects by commercial bothropic antivenom (Bothrops genus). Toxicon, 47: 95-103.

D’Agostini, F.M. 1998. Variação da folidose de Philodryas aestivus (Duméril, Bibron et Duméril, 1854) e a invalidação das subspécies (Serpentes, Colubridae, Xenodontinae, Philodryadini). Biociências, 6: 169-182.

Donnelly, M.A. \& Myers, C.W. 1991. Herpetological results of the 1990 Venezuelan expedition to the summit of Cerro Guaiquinima, with new tepui reptiles. American Museum Novitates, 3017: 1-54.

Donoso-Barros, R. 1974. Descripción de una culebra del Perú. Neotropica, 20: $14-16$.

Dowling, H.G. \& Duellman, W.E. 1978. Systematic herpetology: a synopsis of families and higher categories. HISS Publications (privated printed by the senior author). New York.

Ferrarezzi, H. 1994. Uma sinopse dos gêneros e classificação das Serpentes (Squamata): II. Family Colubridae. Pp. 81-91. In: Nascimento LB, Tristão A, Cotta GA, (Eds.). Herpetologia do Brasil 1. Belo Horizonte, MG, Brazil: Fundação Biodiversitas e Fundação Ezequiel Dias.
Figueroa, A.; McKelvy, A.D.; Grismer, L.L.; Bell, C.D. \& Lailvaux, S.P. 2016. A species-level phylogeny of extant snakes with description of a new colubrid subfamily and genus. PLOSONE, 11: 1-31.

Graboski, R.; Arredondo, J.C.; Grazziotin, F.G.; da Silva, A.A.A.; Prudente, A.L.C.; Rodrigues, M.T.; Bonatto, S.L. \& Zaher, H. 2018. Molecular phylogeny and hemipenial diversity of South American species of Amerotyphlops (Typhlopidae, Scolecophidia). Zoologica Scripta, 48(2): 139-156.

Grazziotin, F.G.; Zaher, H.; Murphy, R.W.; Scrocchi, G.; Benavides, M.A.; Zhang, Y.P. \& Bonatto, S.L. 2012. Molecular phylogeny of the new world Dipsadidae (Serpentes: Colubroidea): a reappraisal. Cladistics, 28: 437-59.

Greene, H.W. \& Jaksic, F.M. 1992. The feeding behavior and natural history of two Chilean snakes, Philodryas chamissonis and Tachymenis chilensis (Colubridae). Revista Chilena de Historia Natural, 65: 485-493

Günther, A. 1858. Catalogue of Colubrine snakes of the British Museum. London, I-XVI, 281p.

Hartmann, P.A. \& Marques, O.A.V. 2005. Diet and habitat use of two sympatric species of Philodryas (Colubridae) in south Brazil. Amphibia-Reptilia, 26 : 25-31.

Jenner, J.V. \& Dowling, H.G. 1985. Taxonomy of American xenodontine snakes: the tribe Pseudoboini. Herpetologica, 41(2): 161-172.

Katoh, K.; Kuma, K.; Toh, H. \& Miyata, T. 2005. MAFFT version 5: Improvement in accuracy of multiple sequence alignment. Nucleic Acids Research, 33: 511-518.

Kearse, M.; Moir, R.; Wilson, A.; Stones-Havas, S.; Cheung, M.; Sturrock, S.; Buxton, S.; Cooper, A.; Markowitz, S.; Duran, C.; Thierer, T.; Ashton, B.; Meintjes, P. \& Drummond, A. 2012. Geneious Basic: An integrated and extendable desktop software platform for the organization and analysis of sequence data. Bioinformatics, 28: 1647-1649.

Lanfear, R.; Frandsen, P.B.; Wright, A.M.; Senfeld, T. \& Calcott, B. 2016. Partition Finder 2: New methods for selecting partitioned models of evolution for molecular and morphological phylogenetic analyses. Molecular Biology and Evolution, 34: 772-773.

Lobo, F. \& Scrocchi, G. 1994. Osteología craneal del género Philodryas (Serpentes: Colubridae). Cuadernos de Herpetología, 8(1): 104-111.

Machado, S.R. 1993. A new genus of Amazonian vine snake (Xenodontinae: Alsophiini). Acta Biologica Leopoldensia, 15: 99-108.

Maglio, V.J. 1970. West Indian xenodontine colubrid snakes: their probable origin, phylogeny, and zoogeography. Bulletin of the Museum of Comparative Zoology, 141: 1-54.

Marques, 0.A.V.; Sawaya, R.J.; Stender-Oliveira, F. \& Franca-Marques, F.G.R. 2006. Ecology of the colubrid snake Pseudablabes agassizii in southeastern South America. Herpetological Journal, 16: 37-45

Miller, M.A.; Pfeiffer, W. \& Schwartz, T. 2010. Creating the CIPRES Science Gateway for inference of large phylogenetic trees. In: Proceedings of the Gateway Computing Environments Workshop (GCE), New Orleans. DOI

Modahl, C.M.; Saviola A.J. \& Mackessy, S.P. 2016. Venoms of Colubrids. In: Gopalakrishnakone, P.; Calvete, J. (Eds.). Venom Genomics and Proteomics. Dordrecht, Springer. p. 51-79. (Toxinology).

Nogueira, C.C.; Argôlo, A.J.S.; Arzamendia, V.; Azevedo, J.A.; Barbo, F.E.; Bérnils, R.S.; Bolochio, B.E.; Borges-Martins, M.; Brasil-Godinho, M.; Braz, H.; Buononato, M.A.; Cisneros-Heredia, D.F.; Colli, G.R.; Costa, H.C.; Franco, F.L.; Giraudo, A.; Gonzalez, R.C.; Guedes, T.; Hoogmoed, M.S.; Marques, O.A.V.; Montingelli, G.G.; Passos, P.; Prudente, A.L.C.; Rivas, G.A.; Sanchez, P.M.; Serrano, F.C.; Silva, N.J.; Strüssmann, C.; Vieira-Alencar, J.P.S.; Zaher, H.; Sawaya, R.J. \& Martins, M. 2019. Atlas of Brazilian snakes: verified point-locality maps to mitigate the Wallacean shortfall in a megadiverse snake fauna. South American Journal of Herpetology, 14(sp): 1-274.

Noonan, B.P. \& Chippindale, P.T. 2006. Dispersal and vicariance: The complex evolutionary history of boid snakes. Molecular Phylogenetics and Evolution, 40: 347-358. 
Oliveira, J.S.; Sant'Anna, L.B.; Oliveira Junior, M.C.; Souza, P.R.M.; Andrade Souza, A.S.; Ribeiro, W.; Vieira, R.P.; Hyslop, S. \& Cogo, J.C. 2017. Local and hematological alterations induced by Philodryas olfersii snake venom in mice. Toxicon, 132: 9-17.

Parker, H.W. 1932. Some new or rare reptiles and amphibians from southern Ecuador. Annals and Magazine of Natural History, 9: 21-26.

Peters, J.A. 1960. The snakes of the subfamily Dipsadinae. Miscellaneous Publications of the Museum of Zoology, University of Michigan, 114: 1-224.

Prudente, A.L.C.; Silva, M.A.A.; Rocha, W.A. \& Franco, F.L. 2008. Morphological variation in Xenoxybelis boulengeri (Procter, 1923) (Serpentes, Xenodontinae, Philodryadini). Zootaxa, 1743: 53-61.

Pyron, R.A.; Burbrink, F.T. \& Wiens, J.J. 2013. A phylogeny and revised classification of Squamata, including 4161 species of lizards and snakes. BMC Evolutionary Biology, 13: 93.

Pyron, R.A.; Burbrink, F.T.; Colli, G.R.; de Oca, A.N.; Vitt, L.J.; Kuczynski, C.A. \& Wiens, J.J. 2011. The phylogeny of advanced snakes (Colubroidea), with discovery of a new subfamily and comparison of support methods for likelihood trees. Molecular Phylogenetics and Evolution, 58: 329-342.

Rambaut, A.; Drummond, A.J.; Xie, D.; Baele, G. \& Suchard, M.A. 2018. Posterior summarisation in Bayesian phylogenetics using Tracer 1.7. Systematic Biology, 67(5): 901-904.

Ronquist, F.; Teslenko, M.; Van der Mark, P.; Ayres, D.L.; Darling, A.; Höhna, S.; Larget, B.; Liu, L.; Suchard, M.A. \& Huelsenbeck, J.P. 2012. MrBayes 3.2: Efficient bayesian phylogenetic inference and model choice across a large model space. Systematic Biology, 61: 539-542.

Sallaberry-Pincheira, N.; Garin, C.F.; González-Acuña, D.; Sallaberry, M.A. \& Vianna, J.A. 2011. Genetic divergence of Chilean long-tailed snake (Philodryas chamissonis) across latitudes: conservation threats for different lineages. Diversity and Distributions, 17, 152-162.

Sánchez, M.; Timoniuk, A.; Maruñak, S.; Teibler, P.; Acosta, 0. \& Peichoto, M. 2014. Biochemical and biological analysis of Philodryas baroni (Baron's Green Racer; Dipsadidae) venom: Relevance to the findings of human risk assessment. Human \& Experimental Toxicology, 33: 22-31.

Stamatakis, A. 2014. RAxML version 8: A tool for phylogenetic analysis and post-analysis of large phylogenies. Bioinformatics, 30: 1312-1313.

Thomas, R.A. 1976. A revision of the South American colubrid snake genus Philodryas Wagler, 1830. Doctoral Thesis, Texas A \& M University.

Thomas, R.A. 1977. A new generic arrangement for Incaspis and mainland South American Alsophis and the status of two additional Peruvian species. Copeia, 1977(4): 648-652.

Thomas, R.A. \& Di Bernardo, M. 2001. Philodryas pallidus (Werner, 1926): A synonym of the colubrid snake Liopholidophis varius (Fischer, 1884) from Madagascar. Journal of Herpetology, 35(1): 120-122.

Thomas, R.A.\& Dixon, J.R. 1977. A new systematic arrangement for Philodryas serra (Schlegel) and Philodryas pseudoserra Amaral (Serpentes: (olubridae). Pierce-Sellards Series, 27: 1-20.

Thomas, R.A. \& Fernandes, R. 1996. The systematic status of Platyinion lividum Amaral, 1923 (Serpentes: Colubridae: Xenodontinae). Herpetologica, 52(2): 271-275.

Thomas, R.A. \& Johnson, J.D. 1984. Philodryas varius (Jan, 1863), a senior synonym of Philodryas borellii Peracca (Serpentes: Colubridae). Journal of Herpetology, 18(1): 80-81.

Thomas, R.A.; Bérnils, R.S.; Moura-Leite, J.C. \& Morato, S.A.A. 2006. Redescription of Ditaxodon taeniatus (Hensel, 1868) (Serpenetes, Colubridae, Xenodontinae): variation, relationships, and distribution. South American Journal of Herpetology, 1: 94-101.
Urra, F.A.; Pulgar, R.; Gutiérrez, R.; Hodar, C.; Cambiazo, V. \& Labra, A. 2015. Identification and molecular characterization of five putative toxins from the venom gland of the snake Philodryas chamissonis (Serpentes: Dipsadidae). Toxicon, 108: 19-31.

Vaidya, G.; Lohman, D.J. \& Meier, R. 2011. SequenceMatrix: concatenation software for the fast assembly of multigene datasets with character set and codon information. Cladistics, 27: 171-180.

Vences, M.; Guayasamin, J.M.; Miralles, A. \& De la Riva, I. 2013. To name or not to name: criteria to promote economy of change in Linnaean classification schemes. Zootaxa, 3636: 201-244.

Vidal, N.; Dewynter, M. \& Gower, D.J. 2010. Dissecting the major American snake radiation: a molecular phylogeny of the Dipsadidae Bonaparte (Serpentes, Caenophidia). Comptes rendus biologies, 333(1): 48-55.

Vidal, N.; Kindl, S.G.;Wong, A. \& Hedges, S.B. 2000. Phylogenetic relationships of xenodontine snakes inferred from $12 \mathrm{~s}$ and $16 \mathrm{~s}$ ribosomal RNA sequences. Molecular Phylogenetics and Evolution, 14(3): 389-402.

Wagler, J.G. 1830. Natürliches System der Amphibien, mit vorangehender Classification der Saugthiere und Vogel. Ein Beitrag zur vergleichenden Zoologie. Munchen, J.G. Cotta schen Buchhandlung. vi + 354p.

Wallach, V.; Williams, K.L. \& Boundy, J. 2014. Snakes of the world: a catalogue of living and extinct species. Boca Raton, CRC Press.

Weinstein, S.A.; Warrell, D.A.; White, J. \& Keyler, D.E. 2011. Medically significant bites by "colubrid" snakes. In: "Venomous" Bites from NonVenomous Snakes, a critical Analysis of Risk and Management of "Colubrid" Snake Bites, Elsevier. p. 33-270.

Weinstein, S.A.; White, J.; Keyler, D.E. \& Warrell, D.A. 2013. Non-frontfanged colubroid snakes: a current evidence-based analysis of medical significance. Toxicon, 69: 103-113.

Zaher, H. 1999. Hemipenial morphology of the South American xenodontine snakes, with a proposal for a monophyletic Xenodontinae and a reappraisal of colubroid hemipenes. Bulletin of the American Museum of Natural History, 240: 1-168.

Zaher, H.; Arredondo, J.C.; Valencia, J.; Arbeláez, E.; Rodrigues, M.T. \& Altamirano-Benavides, M. 2014. A new Andean species of Philodryas (Dipsadidae, Xenodontinae) from Ecuador. Zootaxa, 3785: 469-480.

Zaher, H.; Grazziotin, F.G.; Cadle, J.E.; Murphy, R.W.; Moura-Leite, J.C. \& Bonatto, S.L. 2009. Molecular phylogeny of the advanced snakes (Serpentes, Caenophidia), with an emphasis on South American Xenodontines: a revised classification and descriptions of new taxa. Papéis Avulsos de Zoologia, São Paulo, 49(11): 115-153.

Zaher, H.; Grazziotin, F.G.; Graboski, R.; Fuentes, R.G.; Sánchez-Martinez, P.; Montingelli, G.G.; Zhang, Y-P. \& Murphy, R.W. 2012. Phylogenetic relationships of the genus Sibynophis (Serpentes: Colubroidea). Papéis Avulsos de Zoologia, São Paulo, 52(12): 141-149.

Zaher, H.; Murphy, R.W.; Arredondo, J.C.; Graboski, R.; Machado-Filho, P.R.; Mahlow, K.; Montingelli, G.G.; Bottallo-Quadros, A.; Orlov, N.L.; Wilkinson, M.; Zhang, Y-P. \& Grazziotin, F.G. 2019. Large-scale molecular phylogeny, morphology, divergence-time estimation, and the fossil record of advanced caenophidian snakes (Squamata: Serpentes). PLoS ONE, 14: e0216148.

Zaher, H.; Scrocchi, G. \& Masiero, R. 2008. Rediscovery and redescription of the type of Philodryas laticeps Werner, 1900 and the taxonomic status of P. oligolepis Gomes, 1921 (Serpentes, Colubridae). Zootaxa, 1940: 25-40.

Zaher, H.; Yánez-Muñoz, M.H.; Rodrigues, M.T.; Graboski, R.; Machado, F.A.; Altamirano-Benavides, M.; Bonatto, S.L. \& Grazziotin, F.G. 2018. Origin and hidden diversity within the poorly known Galápagos snake radiation (Serpentes: Dipsadidae). Systematics and Biodiversity, 1-29. 


\section{SUPPLEMENTARY INFORMATION}

Available at: Figshare http://doi.org/10.6084/m9.figshare.13061516.

Extended Figure S1. Best scoring maximum likelihood (ML) tree estimated using RAxML. Numbers on nodes correspond to Bootstrap values.

Extended Figure S2. Maximum Clade Credibility Tree estimated using MrBayes. Numbers on nodes correspond to posterior probability values.

Extended Table S1. Accession and voucher numbers for the sequences of the taxa analyzed here. Codes in bold correspond to new sequences.

Extended Table S2. The partition schemes and models of evolution for the mitochondrial and nuclear genes as selected by PartitionFinder.

Extended Data S1. Concatenated molecular dataset. 
Extended Figure S1. Best scoring maximum likelihood (ML) tree estimated using RAxML. Numbers on nodes correspond to Bootstrap values.

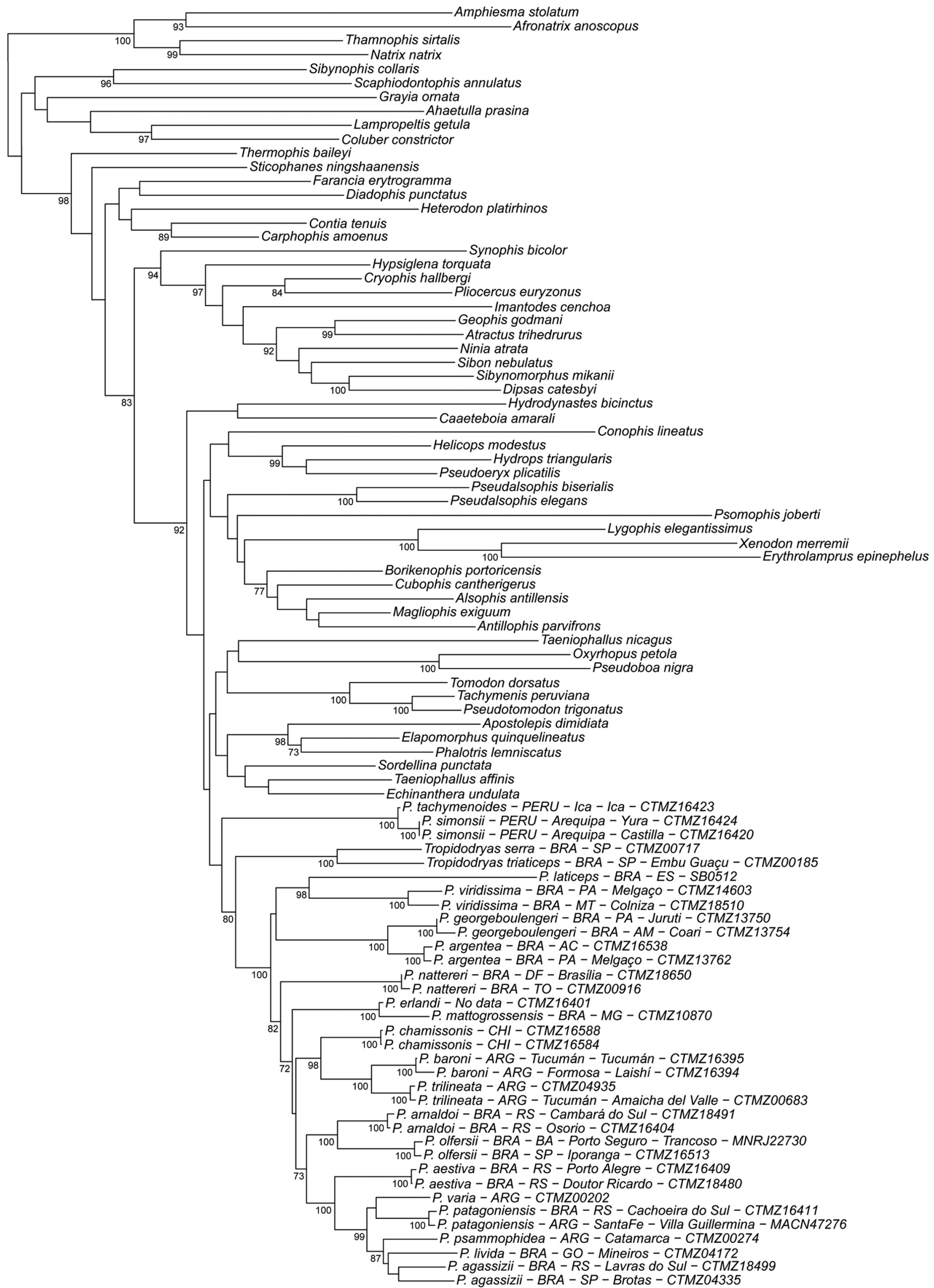


Extended Figure S2. Maximum Clade Credibility Tree estimated using MrBayes. Numbers on nodes correspond to posterior probability values.

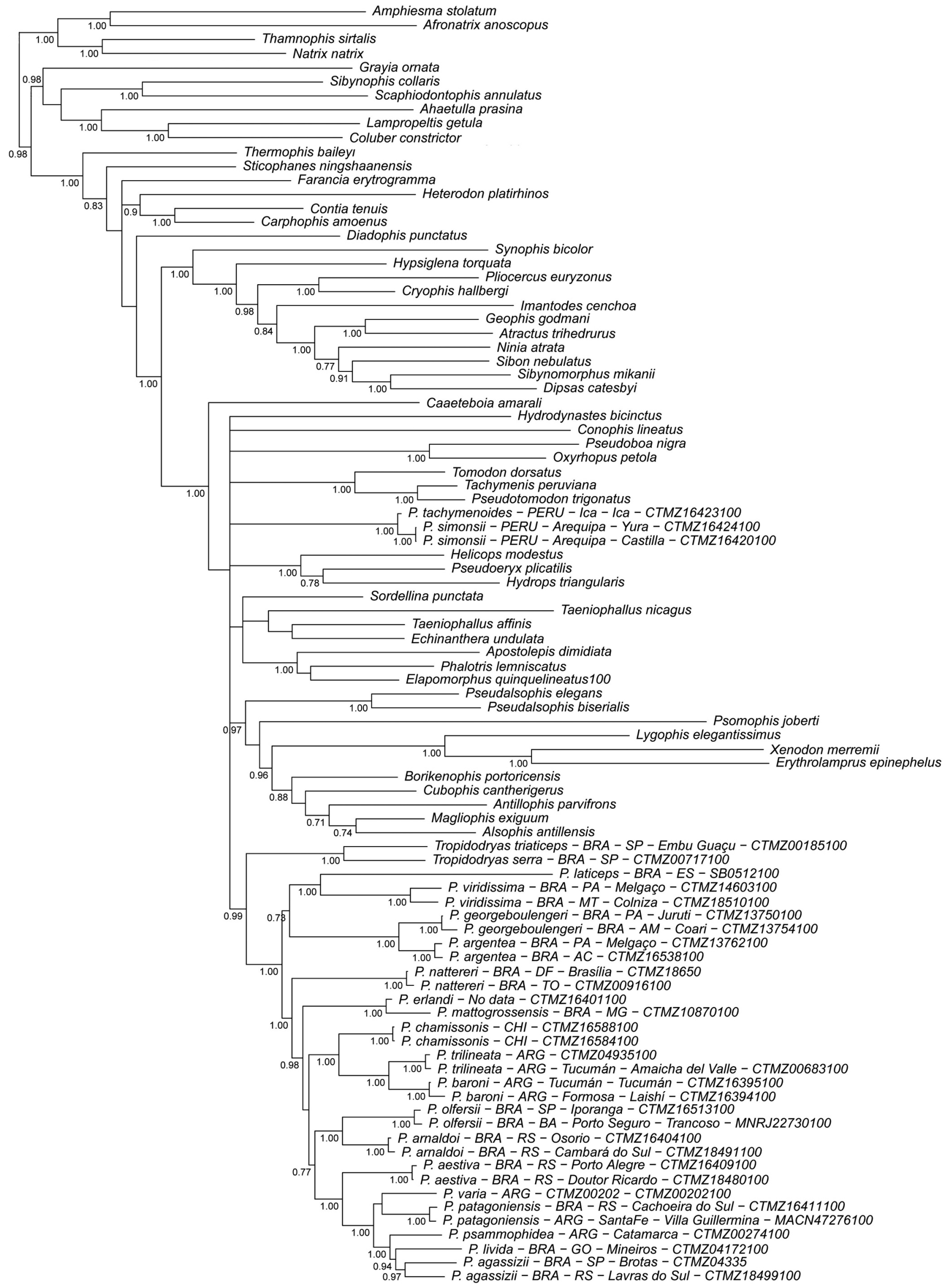


Table S1. Accession and voucher numbers for the sequences of the taxa analyzed here. Codes in bold correspond to new sequences.

\begin{tabular}{|c|c|c|c|c|c|c|c|c|c|}
\hline Family & Subfamily & Tribe & Terminal & $12 \mathrm{~s}$ & BDNF & CMOS & CyT-b & NT3 & $\mathrm{COI}$ \\
\hline Colubridae & & & Ahaetulla prasina & YPX543 & YPX543 & YPX543 & KC010338 & YPX543 & YPX543 \\
\hline Colubridae & & & Coluber constrictor & U96794 & YPX528 & YPX528 & EU180486 & YPX528 & AY122735 \\
\hline Colubridae & & & Lampropeltis getula & AY122821 & YPX511 & YPX511 & FJ997820 & YPX511 & YPX511 \\
\hline Dipsadidae & Carphophiinae & & Carphophis amoenus & AY577013 & - & DQ112082 & AF471067 & - & - \\
\hline Dipsadidae & Carphophiinae & & Contia tenuis & AY577021 & GU112361 & AF471134 & AF471095 & - & - \\
\hline Dipsadidae & Carphophiinae & & Diadophis punctatus & CTMZ04132 & CTMZ04132 & AF471122 & EU193843 & YPX089 & YPX089 \\
\hline Dipsadidae & Dipsadinae & & Atractus trihedrurus & CBGM00028 & CBGM00028 & CBGM00028 & YPX112 & CBGM00028 & CBGM00028 \\
\hline Dipsadidae & Dipsadinae & & Dipsas catesbyi & CBGM00104 & YPX119 & DICA001 & EF078537 & YPX119 & CBGM00104 \\
\hline Dipsadidae & Dipsadinae & & Geophis godmani & CTMZ04114 & YPX123 & - & YPX123 & YPX123 & YPX123 \\
\hline Dipsadidae & Dipsadinae & & Hypsiglena torquata & EU728591 & - & AF471159 & EU728591 & FJ455192 & NC13992 \\
\hline Dipsadidae & Dipsadinae & & Imantodes cenchoa & EU728586 & YPX127 & GQ457865 & EU728586 & YPX127 & NC13988 \\
\hline Dipsadidae & Dipsadinae & & Ninia atrata & GQ457814 & YPX131 & GQ457874 & YPX131 & YPX131 & YPX131 \\
\hline Dipsadidae & Dipsadinae & & Pliocercus euryzonus & TG2201 & TG2201 & TG2201 & - & TG2201 & TG2201 \\
\hline Dipsadidae & Dipsadinae & & Sibon nebulatus & EU728583 & - & AF544736 & EU728583 & FJ455189 & NC13985 \\
\hline Dipsadidae & Dipsadinae & & Sibynomorphus mikanii & GQ457832 & YPX141 & GQ457892 & YPX141 & YPX141 & JQ627383 \\
\hline Dipsadidae & Dipsadinae & & Synophis bicolor & CTMZ0854 & CTMZ0854 & CTMZ854 & CTMZ854 & CTMZ0854 & YPX144 \\
\hline Dipsadidae & Xenodontinae & Alsophiini & Alsophis antillensis & FJ416691 & CTMZ04929 & - & FJ416726 & - & - \\
\hline Dipsadidae & Xenodontinae & Alsophiini & Antillophis parvifrons & YPX108 & YPX108 & - & FJ416740 & YPX108 & YPX108 \\
\hline Dipsadidae & Xenodontinae & Alsophiini & Borikenophis portoricensis & FJ416696 & CTMZ04118 & AF471126 & FJ416732 & - & - \\
\hline Dipsadidae & Xenodontinae & Alsophiini & Cryophis hallbergi & - & - & GQ895807 & EF078496 & GQ334666 & - \\
\hline Dipsadidae & Xenodontinae & Alsophiini & Cubophis cantherigerus & AF158405 & FJ433999 & AF544694 & AF544669 & FJ434100 & - \\
\hline Dipsadidae & Xenodontinae & Alsophiini & Magliophis exiguum & FJ416694 & - & AF471117 & FJ416724 & - & - \\
\hline Dipsadidae & Xenodontinae & Caateboiini & Caaeteboia amarali & GQ457807 & - & GQ457867 & CBGM0239 & - & - \\
\hline Dipsadidae & Xenodontinae & Conophiini & Conophis lineatus & GQ457788 & YPX116 & CTMZ04125 & JQ598924 & - & YPX116 \\
\hline Dipsadidae & Xenodontinae & Echinantherini & Echinanthera undulata & EUN001 & CBGM0292 & EUN002 & CBGM0292 & - & - \\
\hline Dipsadidae & Xenodontinae & Echinantherini & Sordellina punctata & SOPU001 & YPX143 & CTMZ04952 & CTMZ04952 & YPX143 & - \\
\hline Dipsadidae & Xenodontinae & Echinantherini & Taeniophallus affinis & CBGM0427 & CBGM0427 & GQ457853 & CBGM00427 & - & - \\
\hline Dipsadidae & Xenodontinae & Echinantherini & Taeniophallus nicagus & YPX146 & YPX146 & CTMZ0483 & YPX146 & YPX146 & YPX146 \\
\hline Dipsadidae & Xenodontinae & Elapomorphini & Apostolepis dimidiata & CBGM00042 & CBGM00042 & CBGM00042 & CBGM0042 & CBGM00042 & CBGM00042 \\
\hline Dipsadidae & Xenodontinae & Elapomorphini & Elapomorphus quinquelineatus & CBGM00070 & CBGM0070 & CBGM00070 & CBGM0070 & CBGM00070 & CBGM00070 \\
\hline Dipsadidae & Xenodontinae & Elapomorphini & Phalotris lemniscatus & GQ457817 & YPX133 & GQ457877 & CBGM0241 & - & - \\
\hline Dipsadidae & Xenodontinae & Hydrodynastini & Hydrodynastes bicinctus & CBGM00240 & YPX125 & GQ457862 & YPX125 & YPX125 & - \\
\hline Dipsadidae & Xenodontinae & Hydropsini & Helicops modestus & CBGM00197 & CBGM00197 & CBGM00197 & - & CBGM00197 & CBGM00197 \\
\hline Dipsadidae & Xenodontinae & Hydropsini & Hydrops triangularis & CBGM00083 & CBGM00083 & CBGM00083 & AF471039 & YPX126 & CBGM00083 \\
\hline Dipsadidae & Xenodontinae & Hydropsini & Pseudoeryx plicatilis & CBGM00270 & - & GQ457886 & GQ895885 & - & - \\
\hline Dipsadidae & Xenodontinae & Philodryadini & Philodryas aestiva & MCP 5994 & MCP 5994 & MCP 5994 & MCP 5994 & MCP 5994 & MCP 5994 \\
\hline Dipsadidae & Xenodontinae & Philodryadini & Philodryas aestiva & UFRGST 2362 & UFRGST 2362 & UFRGST 2362 & UFRGST 2362 & UFRGST 2362 & UFRGST 2362 \\
\hline Dipsadidae & Xenodontinae & Philodryadini & Philodryas agassizii & CBGM00080 & CBGM00080 & CBGM00080 & CBGM00080 & CBGM00080 & CBGM00080 \\
\hline Dipsadidae & Xenodontinae & Philodryadini & Philodryas agassizii & UFRGST 3219 & UFRGST 3219 & UFRGST 3219 & UFRGST 3219 & UFRGST 3219 & UFRGST 3219 \\
\hline Dipsadidae & Xenodontinae & Philodryadini & Philodryas argentea & CTMZ13762 & CTMZ13762 & CTMZ13762 & CTMZ13762 & CTMZ13762 & CTMZ13762 \\
\hline Dipsadidae & Xenodontinae & Philodryadini & Philodryas argentea & MTR 28272 & MTR 28272 & MTR 28272 & MTR 28272 & MTR 28272 & MTR 28272 \\
\hline Dipsadidae & Xenodontinae & Philodryadini & Philodryas arnaldoi & MCP 6888 & MCP 6888 & MCP 6888 & MCP 6888 & MCP 6888 & MCP 6888 \\
\hline Dipsadidae & Xenodontinae & Philodryadini & Philodryas arnaldoi & UFRGST 3111 & UFRGST 3111 & UFRGST 3111 & UFRGST 3111 & UFRGST 3111 & UFRGST 3111 \\
\hline Dipsadidae & Xenodontinae & Philodryadini & Philodryas baroni & FML 24092 & FML 24092 & FML 24092 & FML 24092 & FML 24092 & FML 24092 \\
\hline Dipsadidae & Xenodontinae & Philodryadini & Philodryas baroni & FML 27110 & FML 27110 & FML 27110 & FML 27110 & FML 27110 & FML 27110 \\
\hline Dipsadidae & Xenodontinae & Philodryadini & Philodryas chamissonis & R0169 & R0169 & R0169 & R0169 & R0169 & R0169 \\
\hline
\end{tabular}


Table S1. Continued.

\begin{tabular}{|c|c|c|c|c|c|c|c|c|c|}
\hline Family & Subfamily & Tribe & Terminal & $12 \mathrm{~s}$ & BDNF & CMOS & Cут-b & NT3 & $\mathrm{COI}$ \\
\hline Dipsadidae & Xenodontinae & Philodryadini & Philodryas chamissonis & R165/A & R165/A & R165/A & R165/A & R165/A & R165/A \\
\hline Dipsadidae & Xenodontinae & Philodryadini & Philodryas erlandi & IB-MB 5624 & IB-MB 5624 & IB-MB 5624 & IB-MB 5624 & IB-MB 5624 & IB-MB 5624 \\
\hline Dipsadidae & Xenodontinae & Philodryadini & Philodryas georgeboulengeri & CTMZ13750 & CTMZ13750 & CTMZ13750 & CTMZ13750 & CTMZ13750 & CTMZ13750 \\
\hline Dipsadidae & Xenodontinae & Philodryadini & Philodryas georgeboulengeri & СTMZ13754 & CTMZ13754 & CTMZ13754 & CTMZ13754 & CTMZ13754 & CTMZ13754 \\
\hline Dipsadidae & Xenodontinae & Philodryadini & Philodryas laticeps & SB0512 & - & - & SB0512 & SB0512 & SB0512 \\
\hline Dipsadidae & Xenodontinae & Philodryadini & Philodryas livida & CTMZ04172 & CTMZ04172 & CTMZ04172 & CTMZ04172 & CTMZ04172 & CTMZ04172 \\
\hline Dipsadidae & Xenodontinae & Philodryadini & Philodryas mattogrossensis & CTMZ10870 & CTMZ10870 & CTMZ10870 & CTMZ10870 & CTMZ10870 & CTMZ10870 \\
\hline Dipsadidae & Xenodontinae & Philodryadini & Philodryas nattereri & CBGM00220 & CBGM00220 & CBGM00220 & AF236806 & CBGM00220 & CBGM00220 \\
\hline Dipsadidae & Xenodontinae & Philodryadini & Philodryas nattereri & CTMZ00916 & CTMZ00916 & CTMZ00916 & СTMZ00916 & CTMZ00916 & CTMZ00916 \\
\hline Dipsadidae & Xenodontinae & Philodryadini & Philodryas olfersii & MTR 18549 & MTR 18549 & MTR 18549 & MTR 18549 & MTR 18549 & MTR 18549 \\
\hline Dipsadidae & Xenodontinae & Philodryadini & Philodryas olfersii & MNRJ22730 & MNRJ22730 & MNRJ22730 & MNRJ22730 & MNRJ22730 & MNRJ22730 \\
\hline Dipsadidae & Xenodontinae & Philodryadini & Philodryas patagoniensis & MCP 5753 & MCP 5753 & MCP 5753 & MCP 5753 & MCP 5753 & MCP 5753 \\
\hline Dipsadidae & Xenodontinae & Philodryadini & Philodryas patagoniensis & MACN47276 & MACN47276 & MACN47276 & MACN47276 & MACN47276 & MACN47276 \\
\hline Dipsadidae & Xenodontinae & Philodryadini & Philodryas psammophidea & CTMZO0274 & CTMZO0274 & CTMZO0274 & CTMZO0274 & CTMZO0274 & CTMZO0274 \\
\hline Dipsadidae & Xenodontinae & Philodryadini & Philodryas simonsii & CORBIDI 11238 & CORBIDI 11238 & CORBIDI 11238 & CORBIDI 11238 & CORBIDI 11238 & CORBIDI 11238 \\
\hline Dipsadidae & Xenodontinae & Philodryadini & Philodryas simonsii & MUSA COL-016 & MUSA COL-016 & MUSA COL-016 & MUSA COL-016 & MUSA COL-016 & MUSA COL-016 \\
\hline Dipsadidae & Xenodontinae & Philodryadini & Philodryas tachymenoides & MUSA COL-007 & MUSA COL-007 & MUSA COL-007 & MUSA COL-007 & MUSA COL-007 & MUSA COL-007 \\
\hline Dipsadidae & Xenodontinae & Philodryadini & Philodryas trilineata & CTMZ00683 & CTMZ00683 & CTMZ00683 & CTMZ00683 & CTMZ00683 & CTMZ00683 \\
\hline Dipsadidae & Xenodontinae & Philodryadini & Philodryas trilineata & CTMZ04935 & CTMZ04935 & CTMZ04935 & CTMZ04935 & CTMZ04935 & CTMZ04935 \\
\hline Dipsadidae & Xenodontinae & Philodryadini & Philodryas varia & CTMZO0202 & CTMZ00202 & CTMZO0202 & CTMZO0202 & CTMZO0202 & CTMZO0202 \\
\hline Dipsadidae & Xenodontinae & Philodryadini & Philodryas viridissima & CTMZ14603 & CTMZ14603 & CTMZ14603 & CTMZ14603 & CTMZ14603 & CTMZ14603 \\
\hline Dipsadidae & Xenodontinae & Philodryadini & Philodryas viridissima & PMJ 254 & PMJ 254 & PMJ 254 & PMJ 254 & PMJ 254 & PMJ 254 \\
\hline Dipsadidae & Xenodontinae & Pseudoboini & Oxyrhopus petola & OXPE001 & CBGM00149 & OXPE001 & GQ334554 & GQ334684 & CBGM00149 \\
\hline Dipsadidae & Xenodontinae & Pseudoboini & Pseudoboa nigra & CTMZ00036 & CTMZ00036 & CTMZ00036 & YPX136 & CTMZ00036 & CTMZ00036 \\
\hline Dipsadidae & Xenodontinae & Psomophiini & Psomophis joberti & CBGM00211 & CBGM00211 & CBGM00211 & YPX137 & YPX137 & CBGM00211 \\
\hline Dipsadidae & Xenodontinae & Saphenophiini & Pseudalsophis biserialis & CTMZ4659 & - & CTMZ4647 & YPX107 & YPX107 & YPX107 \\
\hline Dipsadidae & Xenodontinae & Saphenophiini & Pseudalsophis elegans & AF158401 & CTMZ07428 & CTMZ07428 & CTMZ07428 & - & - \\
\hline Dipsadidae & Xenodontinae & Tachymenini & Pseudotomodon trigonatus & CTMZ00238 & - & CTMZ00238 & - & CTMZ00238 & CTMZ00238 \\
\hline Dipsadidae & Xenodontinae & Tachymenini & Tachymenis peruviana & CBGM00063 & YPX145 & CBGM00063 & - & CBGM00063 & CBGM00063 \\
\hline Dipsadidae & Xenodontinae & Tachymenini & Tomodon dorsatus & GQ457838 & CBGM00217 & GQ457897 & YPX148 & YPX148 & YPX148 \\
\hline Dipsadidae & Xenodontinae & Tropidodryadini & Tropidodryas serra & CTMZ00717 & CTMZ00717 & CTMZ00717 & CTMZ00717 & CTMZ00717 & CTMZ00717 \\
\hline Dipsadidae & Xenodontinae & Tropidodryadini & Tropidodryas striaticeps & CTMZ00185 & CTMZ00185 & CTMZO0185 & CTMZO0185 & CTMZ00185 & CTMZ00185 \\
\hline Dipsadidae & Xenodontinae & Xenodontini & Erythrolamprus epinephelus & MHUAT0694 & MHUAT0694 & MHUAT0694 & - & MHUAT0694 & MHUAT0694 \\
\hline Dipsadidae & Xenodontinae & Xenodontini & Lygophis elegantissimus & CTMZ04988 & CBGM00055 & CBGM00055 & CBGM00055 & CBGM00055 & CBGM00055 \\
\hline Dipsadidae & Xenodontinae & Xenodontini & Xenodon merremii & CBGM00178 & CBGM00178 & CBGM00178 & YPX150 & YPX150 & CBGM00178 \\
\hline Dipsadidae & & & Farancia erytrogramma & CTMZ04131 & YPX122 & - & - & YPX122 & YPX122 \\
\hline Dipsadidae & & & Heterodon platirhinos & CTMZ04116 & YPX568 & YPX568 & YPX568 & GU353271 & - \\
\hline Dipsadidae & & & Sticophanes ningshaanensis & KJ719252 & - & KJ638717 & KJ719252 & - & KJ719252 \\
\hline Dipsadidae & & & Thermophis baileyi & - & - & EU496922 & EU864147 & - & - \\
\hline Grayiidae & & & Grayia ornata & AF158434 & YPX055 & YPX055 & YPX055 & YPX055 & YPX055 \\
\hline Natricidae & & & Afronatrix anoscopus & YPX522 & YPX522 & YPX522 & AF420073 & YPX522 & YPX522 \\
\hline Natricidae & & & Amphiesma stolatum & YPX553 & YPX553 & YPX553 & AF471030 & YPX553 & YPX553 \\
\hline Natricidae & & & Natrix natrix & YPX538 & EU402655 & AF471121 & AY866541 & KF234022 & AY122664 \\
\hline Natricidae & & & Thamnophis sirtalis & YPX539 & YPX539 & DQ902094 & AF420193 & YPX539 & YPX539 \\
\hline Sibynophiidae & & & Scaphiodontophis annulatus & - & YPX080 & GQ927318 & GQ927323 & YPX080 & - \\
\hline Sibynophiidae & & & Sibynophis collaris & YPX535 & YPX535 & YPX535 & KC000121 & - & YPX535 \\
\hline
\end{tabular}


Table S2. The partitions of the mitochondrial and nuclear genome sequences identified by Partition Finder for analysis run in MrBayes and RaxML.

\begin{tabular}{|c|c|c|c|c|}
\hline Method & Partition & Best Model & Subset Partitions & Subset Sites \\
\hline \multirow{12}{*}{ MrBayes } & p1 & $\mathrm{GTR}+\mathrm{I}+\mathrm{G}$ & $12 s$ & $1-510$ \\
\hline & p2 & $\mathrm{K} 80+\mathrm{I}$ & bdnf (p2), bdnf (p1) & $512-1220 \backslash 3,511-1220 \mid 3$ \\
\hline & p3 & $\mathrm{K} 80+\mathrm{I}+\mathrm{G}$ & bdnf $(\mathrm{p} 3)$ & $513-122013$ \\
\hline & $\mathrm{p} 4$ & $H K Y+G$ & $\mathrm{cmos}(\mathrm{p} 1$ & $1221-180613$ \\
\hline & p5 & $\mathrm{K} 80+\mathrm{I}+\mathrm{G}$ & nt3 (p3), nt3 (p2), cmos (p2), cmos (p3) & $3913-4433 \backslash 3,3912-4433 \backslash 3,1222-1806 \backslash 3,1223-1806 \backslash 3$ \\
\hline & p6 & $\mathrm{F} 81+\mathrm{I}+\mathrm{G}$ & $\operatorname{coi}(\mathrm{p} 1)$ & $1807-2913 \backslash 3$ \\
\hline & p7 & GTR+G & $\operatorname{coi}(\mathrm{p} 2)$ & $1808-2913 \backslash 3$ \\
\hline & $\mathrm{p} 8$ & SYM+I+G & $\operatorname{coi}(\mathrm{p} 3)$ & $1809-2913 \backslash 3$ \\
\hline & p9 & $\mathrm{GTR}+\mathrm{G}$ & cytb (p1) & $2914-391013$ \\
\hline & p10 & $\mathrm{GTR}+\mathrm{G}$ & cytb (p2) & $2915-391013$ \\
\hline & p11 & $\mathrm{HKY}+\mathrm{G}$ & cytb (p3) & $2916-391013$ \\
\hline & p12 & $\mathrm{HKY}+\mathrm{G}$ & nt3 (p1) & $3911-4433 \backslash 3$ \\
\hline \multirow{14}{*}{ RAxML } & p1 & $\mathrm{GTR}+\mathrm{G}$ & $12 \mathrm{~s}$ & $1-510$ \\
\hline & p2 & $\mathrm{GTR}+\mathrm{G}$ & $\operatorname{bdnf}(1)$ & $511-1220 \backslash 3$ \\
\hline & p3 & $\mathrm{GTR}+\mathrm{G}$ & $\operatorname{bdnf}(2), \operatorname{cmos}(3)$ & $512-122013,1223-1806 \backslash 3$ \\
\hline & $\mathrm{p} 4$ & $\mathrm{GTR}+\mathrm{G}$ & bdnf (3) & $513-122013$ \\
\hline & p5 & $\mathrm{GTR}+\mathrm{G}$ & $\operatorname{cmos}(1)$ & $1221-180613$ \\
\hline & p6 & $\mathrm{GTR}+\mathrm{G}$ & $\operatorname{cmos}(2), \mathrm{nt} 3(3)$ & $1222-1806 \backslash 3,3913-4433 \backslash 3$ \\
\hline & p7 & $\mathrm{GTR}+\mathrm{G}$ & $\operatorname{coi}(1)$ & $1807-2913 \backslash 3$ \\
\hline & $\mathrm{p} 8$ & $\mathrm{GTR}+\mathrm{G}$ & $\operatorname{coi}(2)$ & $1808-2913 \backslash 3$ \\
\hline & p9 & $\mathrm{GTR}+\mathrm{G}$ & $\operatorname{coi}(3)$ & $1809-2913 \backslash 3$ \\
\hline & $\mathrm{p} 10$ & $\mathrm{GTR}+\mathrm{G}$ & cytb (1) & $2914-391013$ \\
\hline & p11 & $\mathrm{GTR}+\mathrm{G}$ & cytb (2) & $2915-391013$ \\
\hline & p12 & $\mathrm{GTR}+\mathrm{G}$ & cytb (3) & $2916-391013$ \\
\hline & $\mathrm{p} 13$ & $\mathrm{GTR}+\mathrm{G}$ & nt3 (1) & $3911-443313$ \\
\hline & P14 & $\mathrm{GTR}+\mathrm{G}$ & $\mathrm{nt} 3(2)$ & $3912-4433 \backslash 3$ \\
\hline
\end{tabular}




\section{Erratum}

In the article "Molecular phylogeny of the tribe Philodryadini Cope, 1886 (Dipsadidae: Xenodontinae): Rediscovering the diversity of the South American Racers", http://doi.org/10.11606/18070205/2020.60.53, published in the Journal Papéis Avulsos de Zoologia, Volume 60: e20206053,

\section{In the Acknowledgments:}

\section{Where you read:}

We are in dept with the curators and institutions staff who granted us access to the samples for obtention of molecular evidence. We thank J. Battilana for her help during acquisition of molecular data. We thank F. Curcio and L.J. Vitt for providing photographs of $P$. nattereri, X. boulengeri and P. olfersii used in Fig. 2. We are grateful for the comments from two reviewers whose suggestions improved this manuscript. This study was financed in part by the Coordenação de Aperfeiçoamento de Pessoal de Nível Superior - Brasil (CAPES) - Finance Code 001. FGG was supported by FAPESP (grants 2012/08661-3 and 2016/13469-5). HZ, MTR, and SLB are grateful to Conselho Nacional de Desenvolvimento Científico e Tecnológico (CNPq) for continuing financial support. SLB and MTR were supported by FAPERGS and FAPESP (grants 2003/10335-8 and 2011/50146-6), respectively. This study was funded by Fundação de Amparo à Pesquisa do Estado de São Paulo (FAPESP grants 2011/50206-9 and 2016/50127-5) to HZ.

\section{Read it:}

We are in dept with the curators and institutions staff who granted us access to the samples for obtention of molecular evidence. We thank C. Sarturi (PUCRS), J. Battilana (MZUSP), and N. da Rós (LETA) for their help during the acquisition of molecular data. We thank F. Curcio and L.J. Vitt for providing photographs of $P$. nattereri, $X$. boulengeri and $P$. olfersii used in Fig. 2. We are especially thankful to R. Bernils and R. Rabello-Reis (UFES) for the tissue sample of Chlorosoma laticeps (ICMBio/SISBio permit number 57585). We are grateful for the comments from two reviewers whose suggestions improved this manuscript. This study was financed in part by the Coordenação de Aperfeiçoamento de Pessoal de Nível Superior - Brasil (CAPES) - Finance Code 001. FGG was supported by FAPESP (grants 2012/08661-3 and 2016/13469-5). HZ, MTR, and SLB are grateful to Conselho Nacional de Desenvolvimento Científico e Tecnológico (CNPq) for continuing financial support. SLB and MTR were supported by FAPERGS and FAPESP (grants 2003/10335-8 and 2011/50146-6), respectively. This study was funded by Fundação de Amparo à Pesquisa do Estado de São Paulo (FAPESP grants 2011/50206-9 and 2016/50127-5) to HZ. 